\title{
Numerical Model and Performance Validation of a Small-Scale Concentrating Solar Thermal Power Plant in Louisiana
}

\author{
Jonathan R. Raush ${ }^{1}$, Kenneth Ritter ${ }^{1}$, Matthew Prilliman', Myles Hebert ${ }^{1}$, Zhao Pan², \\ Terrence L. Chambers ${ }^{1}$ \\ ${ }^{1}$ Department of Mechanical Engineering, University of Louisiana at Lafayette, Lafayette, USA \\ ${ }^{2}$ Deparment of Mechanical Engineering, Brigham Young University, Provo, USA \\ Email: *jraush@louisiana.edu
}

How to cite this paper: Raush, J.R., Ritter, K., Prilliman, M., Hebert, M., Pan, Z. and Chambers, T.L. (2018) Numerical Model and Performance Validation of a Small-Scale Concentrating Solar Thermal Power Plant in Louisiana. Journal of Power and Energy Engineering, 6, 112-140.

https://doi.org/10.4236/jpee.2018.69011

Received: December 16, 2017

Accepted: September 27, 2018

Published: September 30, 2018

Copyright $\odot 2018$ by authors and Scientific Research Publishing Inc. This work is licensed under the Creative Commons Attribution-NonCommercial International License (CC BY-NC 4.0).

http://creativecommons.org/licenses/by-nc/4.0/

\begin{abstract}
A simplified numerical model of a small-scale $(25-100 \mathrm{kWe})$ parabolic concentrating solar power (CSP) plant is presented that can be utilized during the planning stages for a CSP plant, utilizing only simplified information that would be available at the preliminary stages of a project. This is important because existing models currently used for planning purposes, such as the System Advisor Model (SAM) from the National Renewable Energy Laboratory (NREL), do not cover small-scale CSP plants. The model can be used to predict real-time performance, or it can be used with TMY data to estimate annual performance. The model was validated using performance data from an operating small-scale CSP power plant, which is a unique contribution of this work. The results showed that the model correlated well with actual operating measurements for all seasons of the year, and provided a useful tool for planning of future small-scale CSP plants.
\end{abstract}

\section{Keywords}

Solar Thermal, Modeling, Validation, Organic Rankine Cycle, Parabolic Trough

\section{Introduction}

The accurate prediction of any power plant's operation and performance is crucial in order to determine the feasibility of a potential project. Resolving issues due to site selection, such as effect of the local irradiance, incidence angle modifiers (IAM), array configuration, and soiling, or the degradation of concentrating mirror reflectance as a result of dust accumulation [1], require the use of a 
reliable model with known uncertainties. In addition, the financial bankability of a project will rest upon assurances derived from trusted modeling of the plant performance, local solar resource, and operation \& maintenance (O\&M) modeling, among other concerns. While there have been numerous numerical models produced to simulate the performance of solar power plants of various configurations, a search of the literature reveals the availability of models that are either complex, requires detailed knowledge of the proposed facility for a single set of configurational parameters, or lacks data validation from similar plant sizes and locations [2]-[19]. Solver schemes may include finite element, finite volume, or other iterative or non-discrete methods. At the initial stages of design, with only limited parameters known, a simplified modeling strategy is needed to predict and evaluate the performance and local feasibility of the full system. A simplified modeling approach and analysis is presented in this paper. Additionally, there is a need for operating data for validation of the many numerical models that have been presented [20]. The University of Louisiana at Lafayette (UL Lafayette) Solar Thermal Applied Research and Testing (START) Laboratory has developed a small-scale organic Rankine cycle (ORC) CSP power plant for pilot testing and demonstration of solar thermal power for the first time in Louisiana [21] [22], as shown in Figure 1 below. The opportunity exists, therefore, to produce an experimentally validated numerical model of a physical system utilizing high fidelity, high resolution test data. The numerical model presented here attempts to utilize data that would be available at the planning stages of a distributed scale power plant $(25-100 \mathrm{kWe})$. For validation, the parameters utilized match those of START Lab, but they could be adjusted to consider a fully parameterized plant of this scale.

The model determined the temperature, thermodynamic properties, and the generated power of the START Lab using locally generated inputs of ambient temperature, humidity, and DNI. Once the simulation model was constructed, model validation was conducted comparing model outputs to experimentally measured outputs. A comparison between measured data and simulated data is presented below.

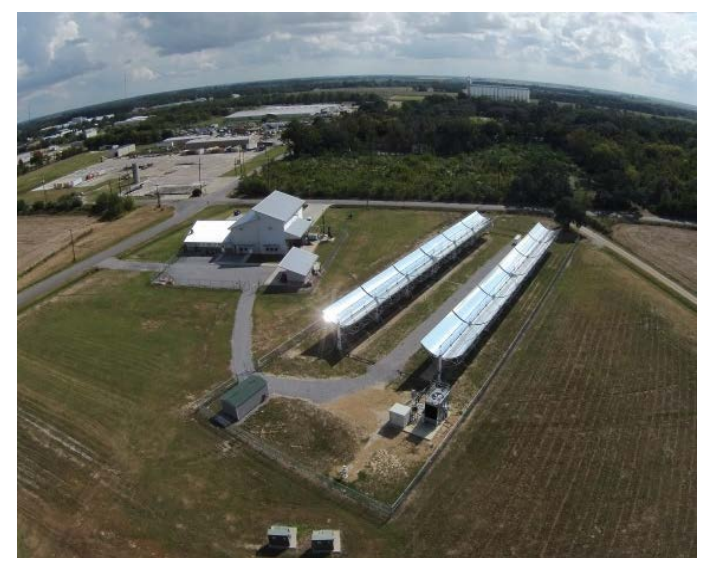

Figure 1. UL Lafayette START Lab. 


\section{Background}

Due to the nature of solar power production, larger solar power plants on a commercial scale are generally more economically feasible, and most previous modeling research emphasizes the detailed modeling of large scale power plants for optimum feasibility. Regarding similar power plant configurations to the one constructed at UL Lafayette, various models emphasizing the thermodynamic potential of ORC working fluids and configurations have been presented [21].

Existing models have been geared toward differing target scales (commercial or central generating vs. distributed), and they have employed a variety of approaches (commercial software vs. open source, physics-based vs. empirical, incorporating energy storage or financial analysis models). Steady-state and transient models have been developed based on the Engineering Equation Solver (EES) software, Aspen Plus process simulator, Modelica, Automation studio, System Advisor Model (SAM), among others. Due to the detailed modeling approach they employ, over 50 input parameters might be required for these types of models [16] [18] [22] [23] [24] [25]. All of that detailed information might not be known at the preliminary planning stage of a project. Also, these models were primarily built to predict the performance of large scale grid-connected renewable power plants, which makes them difficult to accurately extend to small-scale power plant systems.

Small-scale solar power plant system models recently have described solar organic Rankine cycles, parabolic through collectors, thermal storage, and alternatives to turbines such as scroll expanders [26] [27] [28]. However, these models often lacked validation from actual operating systems, and employed many parameters (some empirical) rarely available during the early design phase of a unique system. Prior numerical simulations used to design solar thermal power systems have been either proprietary or devoid of a fully reported source code, making them inaccessible or problematic for adoption or use. Such models have depended on extensive numerical procedures which clouded the physical picture preventing understanding of how component and system performance vary with the principal operating and input parameters [20].

This work describes and validates analytic modeling of the energy flows in a parabolic trough solar thermal power plant with a Rankine cycle heat engine. The relationships presented here are straightforward to implement and evaluate, relating the heat transfer within the solar collectors to the power cycle and the efficiencies of the various components.

The comparison of simulations against experimental performance currently has considerable limitations. Published experimental measurements of any meaningful extent for such solar thermal power plants are exceptionally limited [20], [29]. Measurements of both direct normal irradiance (DNI) and the requisite detailed solar thermal power plant performance (including separate monitoring of the collector field and the turbine block) appear to be scarce. Available monthly figures for all required measurements are currently limited to a single 
year with hourly data limited to a single clear day at the large-scale installation in Kramer Junction, CA, US [30].

In can be seen that for a unique system such as the pilot scale ORC CSP plant at UL Lafayette a modeling strategy which requires only limited known quantities to be employed while design considerations such as site location, collector area, collector type, solar multiple, heat engine (steam, ORC, Brayton, etc.) would prove useful. In this work, a simplified model for an ORC CSP plant is presented using very limited and only necessary parameters, which is suitable for the early stages of the design process. Also, Simulink is employed as the modeling tool [31], a popular simulation and design package in the engineering community. The modeling approach presented in this study can be easily adopted and employed to study configurations of systems not considered here. In addition, time series-based simulation in Simulink easily allows the use of local weather data as an input, either modeled or historical. The Simulink-based model developed will provide a general system framework that will be easy to extend in a straightforward and natural fashion.

\section{Method and Model Description}

The numerical model was constructed utilizing the integration of three fluid loops via counter-flow heat exchanger: the solar collector field, which contains the water and $15 \%$ wt. ethylene glycol mixture heat transfer fluid (HTF), the power block, which consists of an organic Rankine cycle containing the R245fa working fluid (WF), and a cooling loop, which consists of a condensing cooling tower containing cooling water. Figure 2 represents the model as subdivided. A description of each section is provided as follows:

1) WF evaporator/boiler outlet to turbine inlet

2) WF turbine outlet to condenser inlet

3) WF condenser outlet to pump inlet

4) WF pump outlet to boiler inlet

5) HTF pump to west solar collector inlet

6) HTF west collector outlet to east collector inlet

7) HTF east collector outlet to ORC boiler inlet

8) HTF boiler exit to HTF pump

9) Cooling water - cooling tower outlet to WF condenser inlet

10) Cooling water - WF condenser outlet to cooling tower inlet

\subsection{Solar Collector Field}

The START Lab solar loop utilizes Gossamer Space Frames parabolic Large Aperture Troughs (LATs) to transfer heat captured from the sun to the HTF (Figure 3). The LAT geometry (aperture area) was an input to the numerical model, however reflective performance was not (assumed ideal). The heat collection element (HCE) was the Schott PTR 70 receiver consisting of a non-corrosive stainless steel pipe mounted inside of borosilicate envelope. The inner pipe 


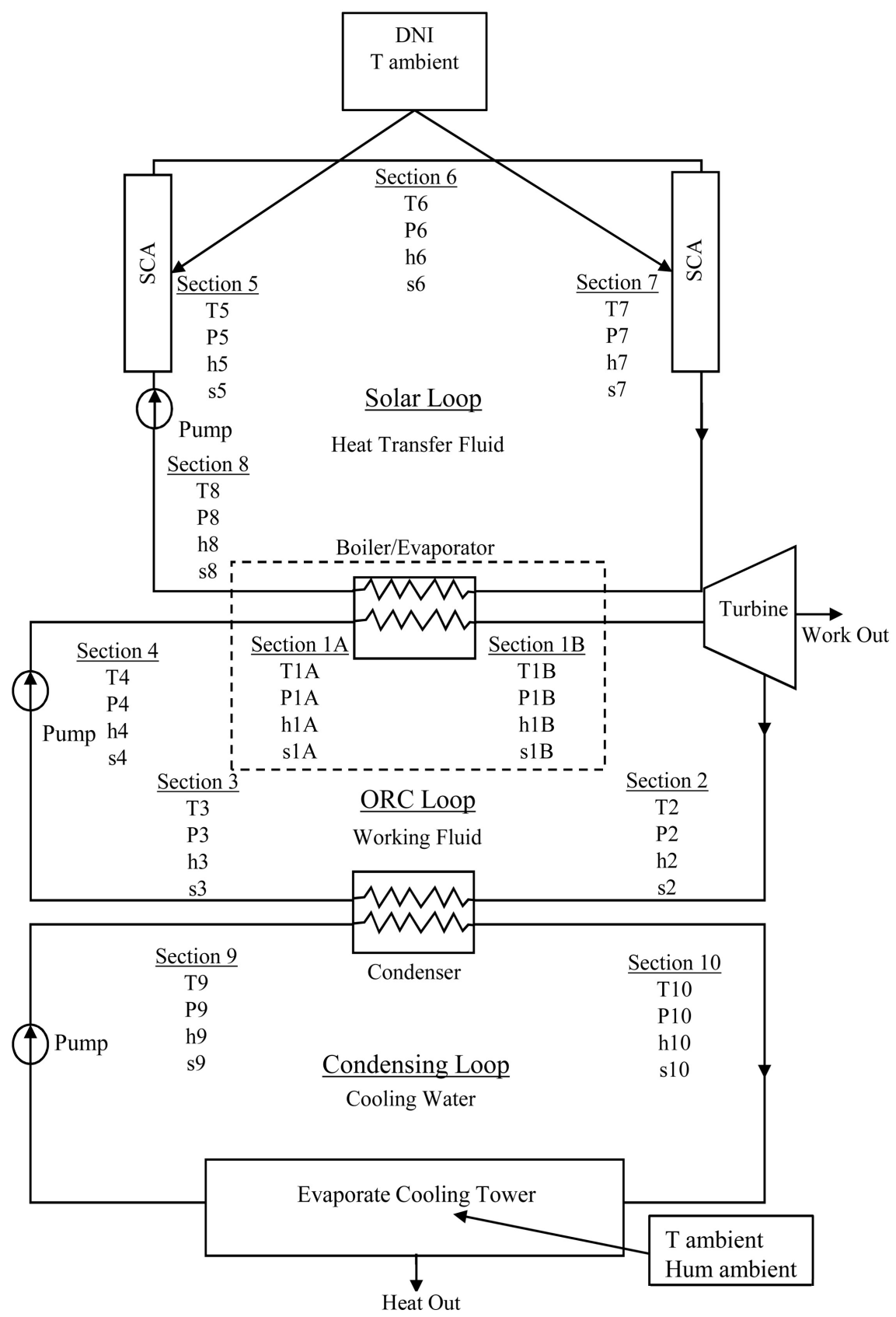

Figure 2. Numerical model system diagram.

has a high-absorptivity coating with vacuum in the annular space to minimize convection losses. The HCE geometry and material properties (absorptivity, reflectivity, etc.) were utilized as inputs to the model, as published by the manufacturer. Table 1 lists all model inputs for the referenced system.

Parameters chosen for the numerical model were selected based on the START lab.

\subsection{Power Block}

Organic fluids are characterized by their low boiling temperature and positive 


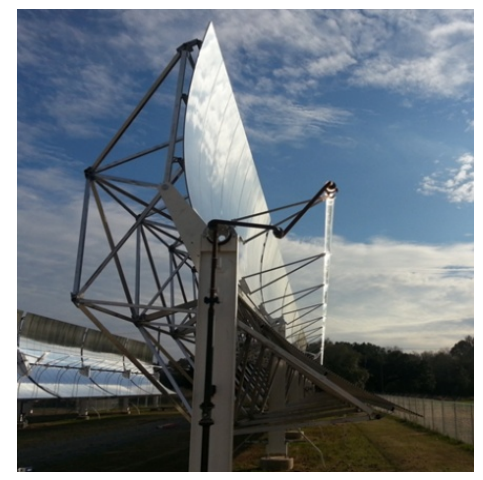

Figure 3. START Lab LAT.

Table 1. Parameters to numerical model.

\begin{tabular}{|c|c|c|c|}
\hline SYMBOL & DESCRIPTION & VALUE & units \\
\hline$C_{P, H T F}$ & Specific heat, heat transfer fluid & 4.186 & $\mathrm{~J} /\left(\mathrm{g} \cdot{ }^{\circ} \mathrm{C}\right)$ \\
\hline$C_{P, W F}$ & Specific heat, working fluid & 1.330 & $\mathrm{~J} /\left(\mathrm{g} \cdot{ }^{\circ} \mathrm{C}\right)$ \\
\hline $\mathrm{DNI}_{\text {min }}$ & Minimum radiation for system start-up & 350 & $\mathrm{~W} / \mathrm{m}^{2}$ \\
\hline Lat & Latitude & $30^{\circ} 13^{\prime} 27^{\prime \prime N}$ & \\
\hline$D_{5}$ & Outside diameter of HCE glass envelope & 0.125 & $\mathrm{~m}$ \\
\hline$\varepsilon_{5}$ & Emissivity of outer surface of glass envelope & 0.093 & \\
\hline$\alpha_{A B S}$ & Absorptivity of HCE selective coating & 0.955 & \\
\hline$\eta_{E N V}$ & Effective optical efficiency of HCE envelope & 0.67 & \\
\hline$\alpha_{E N V}$ & Absorptivity of HCE glass envelope & 0.20 & \\
\hline$A$ & Reflective area of one SCA & 525 & $\mathrm{~m}^{2}$ \\
\hline$L$ & Length of one HCE receiver section & 6 & $\mathrm{~m}$ \\
\hline$T_{5, S T}$ & Glass envelope outer surface initial temperature & 96.3 & C \\
\hline$K_{56}$ & Thermal conductance of air at $\mathrm{T}_{5-6}$ & 0.6969 & $\mathrm{~W} /(\mathrm{m} \cdot \mathrm{K})$ \\
\hline$\alpha_{56}$ & Thermal diffusivity of air at $T_{5-6}$ & 0.00002207 & $\mathrm{~m}^{2} / \mathrm{s}$ \\
\hline$v_{56, S T}$ & Kinematic viscosity of air at $\mathrm{T}_{5-6}$ & 0.000001568 & $\mathrm{~m}^{2} / \mathrm{s}$ \\
\hline$T_{5}$ & Initial HTF temperature entering solar panel & 28 & ${ }^{\circ} \mathrm{C}$ \\
\hline$T_{4}$ & Initial WF temperature entering boiler & 18 & ${ }^{\circ} \mathrm{C}$ \\
\hline$T_{9}$ & $\begin{array}{l}\text { Initial cooling water temperature } \\
\text { entering condenser }\end{array}$ & 23.11 & ${ }^{\circ} \mathrm{C}$ \\
\hline$\eta_{B}$ & Thermal efficiency of boiler & 0.85 & \\
\hline$\eta_{t u r b}$ & Thermal efficiency of turbine/expander & 0.75 & \\
\hline$\eta_{\text {cond }}$ & Thermal efficiency of condenser & 0.60 & \\
\hline$\eta_{\text {pump }}$ & Isentropic efficiency of pump & 0.60 & \\
\hline$\eta_{g e n}$ & Electric efficiency of generator & 0.91 & \\
\hline$\eta_{C T}$ & Thermal efficiency of cooling tower & 0.75 & \\
\hline$\dot{m}$ & Mass flow rate of condensing loop & 12.6 & $\mathrm{~kg} / \mathrm{s}$ \\
\hline$\dot{m}$ & Mass flow rate of HTF & 6.14 & $\mathrm{~kg} / \mathrm{s}$ \\
\hline$\dot{m}$ & Initial mass flow rate of WF & 0.859 & $\mathrm{~kg} / \mathrm{s}$ \\
\hline$P_{l o w}$ & Low pressure point of WF & 0.142 & $\mathrm{MPa}$ \\
\hline$P_{\text {high }}$ & High pressure point of WF & 0.716 & MPa \\
\hline$\sigma$ & Stefan-Boltzmann constant & $5.67037 \times 10^{-08}$ & $\mathrm{~W} /\left(\mathrm{m}^{2} \cdot \mathrm{K}^{4}\right)$ \\
\hline
\end{tabular}


saturated vapor slope on a T-s diagram, illustrated in Figure 4. The benefit of this "drying" characteristic is that for isentropic expansion in the turbine (3- 4 in Figure 4), condensation can be avoided. This property eliminates the need for superheating of the working fluid, which reduces cost and complexity and is a departure from traditional steam cycles. A drawback of the subcritical ORC is the lower Carnot efficiencies relative to steam cycles as a result of the generally lower operating temperatures required [32]. The organic Rankine cycle installed at the START Lab is the ElectraTherm Green Machine series 4000, capable of producing up to $65 \mathrm{kWe}$. This ORC comes as a turnkey assembly, and consists of an evaporator, twin screw expander, condenser, pump, and pre-heater. The working fluid of the ORC is pentafluoropropane (HFC-R245fa), which has a low boiling temperature $\left(15.3^{\circ} \mathrm{C}\right.$ at $\left.1 \mathrm{~atm}\right)$. As in a Rankine cycle, the WF is vaporized in the evaporator using the energy from the HTF in the Solar Collector Field. The high-pressure vapor undergoes expansion through the twin screw expander, coupled to an AC generator. The low-pressure vapor from the turbine is condensed, utilizing an evaporative cooling tower to supply the cooling loop. The low-pressure liquid then undergoes compression to the working pressure of the evaporator. Figure 5 shows modeled results of ORC performance versus resource temperature while Figure 6 shows power output for the ORC with inlet temperature (hot water).

\subsection{Simplifying Assumptions}

There were several simplifying assumptions employed in order to keep the model as simple as possible (limiting number of process parameters needed), while still providing results with limited uncertainty so that usefulness is maximized. The simplifying assumptions are tabulated in Table 2.

Many of the assumptions $(2,3,4,5,10)$ could be made due to the minimal effect on calculated system performance needed at the initial stages of design;

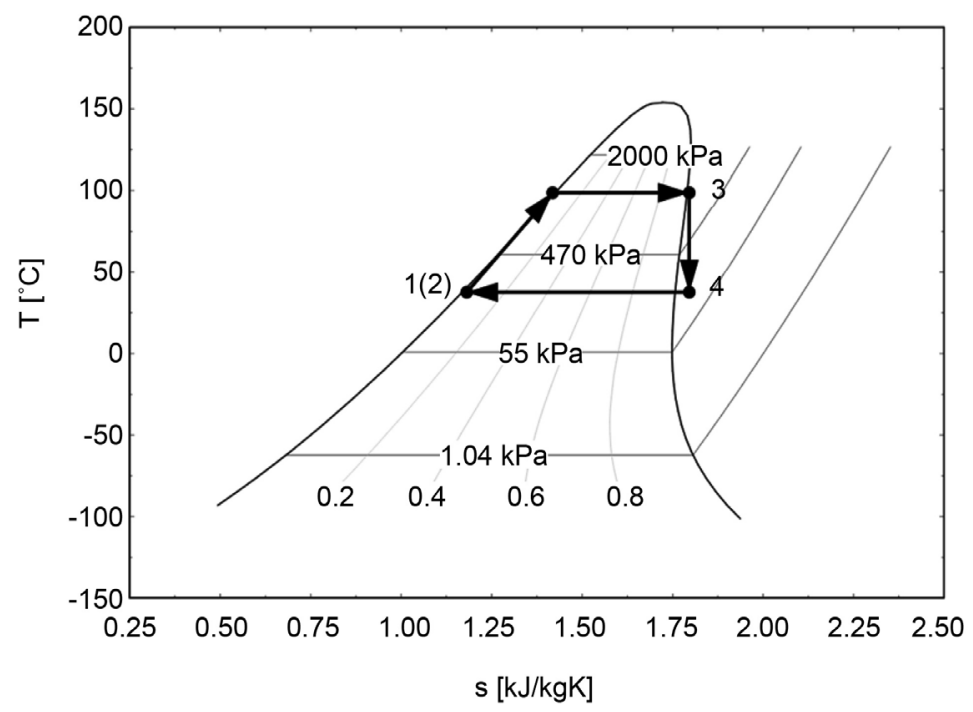

Figure 4. Organic Rankine cycle [33]. 


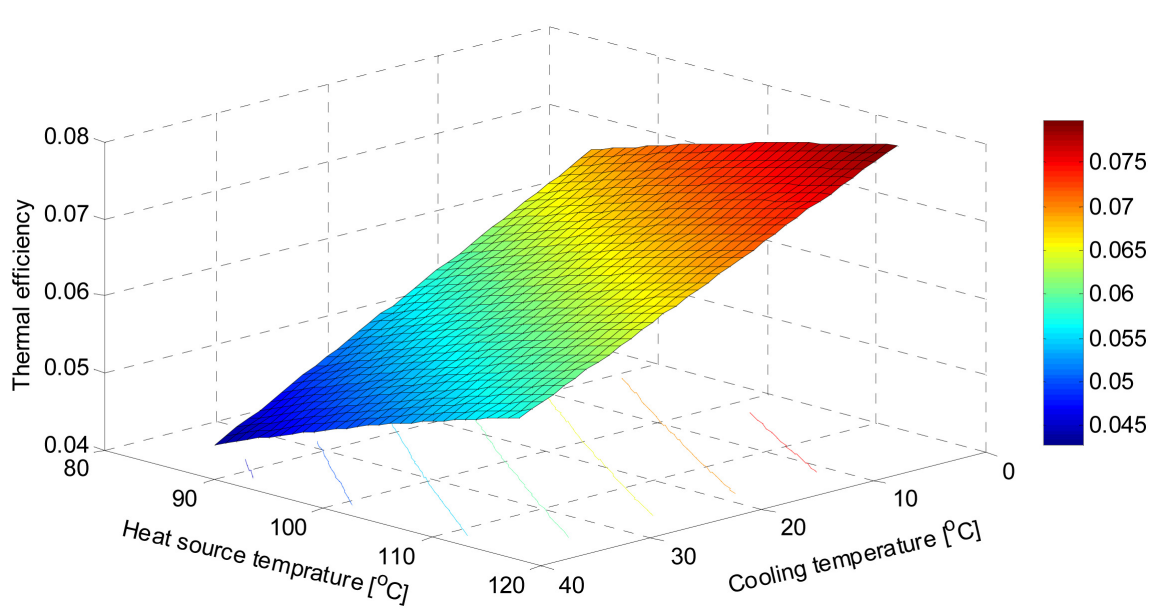

Figure 5. ElectraTherm ORC efficiency vs resource temperatures.

Green Machine Net Power Output-Water Cooled

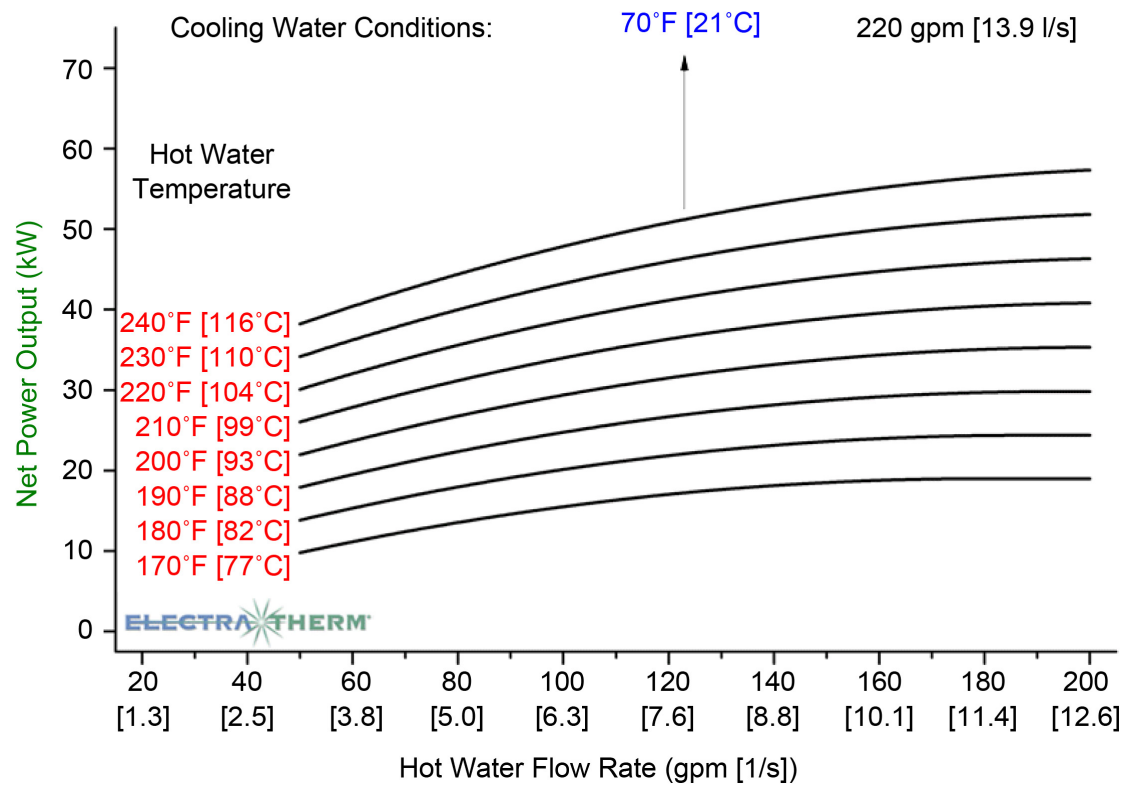

Figure 6. Green Machine output vs resource temperature and flow rate [34].

while for others $(1,8,9,10)$ more specificity regarding a certain configuration would be required and the model could be easily extended to handle the addition if required. The remaining assumptions $(6,7,11)$ are functions of investment in maintenance of a plant that will come after operation begins.

Regarding boiler/evaporator performance, the value of the heat transferred, $Q_{i n}$, in the boiler was determined from the HTF inlet temperature $\left(T_{7}\right)$, flowrate, and an assumed boiler efficiency (a model parameter), effectively a boiler pinch point, where the pinch-point temperature is defined as the minimum temperature difference occurring in the heat exchanger. This occurs at the WF liquid saturation point in most cycles. The WF is assumed to be saturated liquid leaving the evaporator. The temperature of the WF exiting the condenser is assumed 
Table 2. Model simplifying assumptions.

\begin{tabular}{|c|c|c|}
\hline & Description & Model affected \\
\hline 1 & Pre-heating, recuperation, cascading neglected & ORC Loop \\
\hline 2 & Constant fluid flowrates & Solar loop, Cooling loop \\
\hline 3 & Constant fluid specific heats over temperature range & $\begin{array}{l}\text { Solar loop, ORC loop, } \\
\text { Cooling loop }\end{array}$ \\
\hline 4 & Collector tracking error neglected & Solar loop \\
\hline 5 & Wind speed neglected & Solar loop \\
\hline 6 & Soiling neglected (perfect mirror specularity) & Solar loop \\
\hline 7 & $\begin{array}{l}\text { All mirrors, reflectors and HCE tubes assumed unbroken and } \\
\text { in good working order }\end{array}$ & Solar loop \\
\hline 8 & Incident Angle Modifiers neglected & Solar loop \\
\hline 9 & Balance of plant piping perfectly insulated & Solar loop, Cooling loop \\
\hline 10 & Thermal inertia neglected & $\begin{array}{l}\text { Solar loop, ORC loop, } \\
\text { Cooling loop }\end{array}$ \\
\hline 11 & Power plant availability due to maintenance neglected & System \\
\hline
\end{tabular}

equivalent to the cooling water leaving the condenser (and confirmed through observation (Figure 7).

The HTF temperature at the boiler outlet was then determined from the constant mass flow rates of $6.14 \mathrm{~kg} / \mathrm{s}$ and $1.849 \mathrm{~kg} / \mathrm{s}$ (parameters) the heat exchanger efficiency, $\eta_{B}$, and temperature rise in the evaporator, $T_{8}$.

$$
\begin{gathered}
\eta_{B}=\frac{Q_{i n, R 245}}{Q_{i n, H T F}} \\
T_{8}=T_{7}-\eta_{B} \frac{m_{O R C} c_{p(T 1 A-T 1 B) R 245}}{m_{H T F} c_{p}} \\
T_{3}=T_{10}
\end{gathered}
$$

\section{System Model}

\subsection{Solar Loop}

The solar loop incorporated a heat transfer model to calculate the rise in temperature as water flows through the solar panels. The model was a one dimensional steady-state energy balance of the cross section of the receiver that was modified from the model developed in the same manner as the Forristall heat transfer model for parabolic trough receivers originally implemented in Engineering Equation Solver (EES) [35].

The model takes into account the heat gained by the absorption of solar irradiation in the steel pipe and the glass tube. It also takes into account the convection, radiation and convection heat losses of the glass envelope. Figure 8 depicts the one-dimensional setup of the heat transfer model.

To calculate the energy gain and temperature rise of the HTF through the 


\section{Condenser Outlet Temperatures}

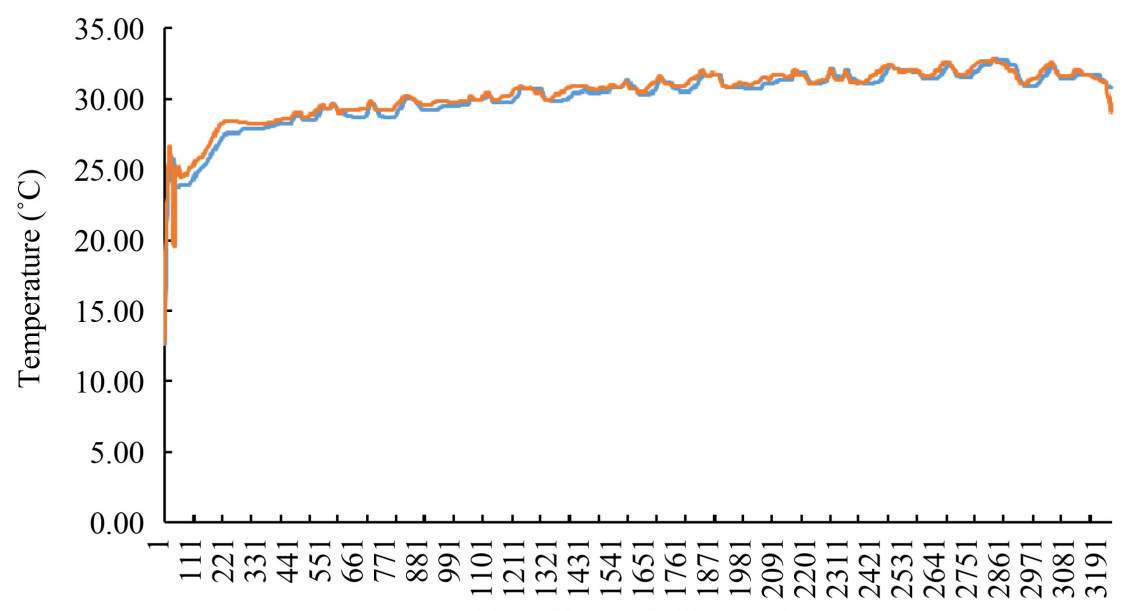

Time (1 sample/5 seconds)

— Refrigerant Tank Outlet Temp (T_3)—Cold Water Outlet Temp

Figure 7. Measured values of condenser outlet temperatures of water and refrigerant.

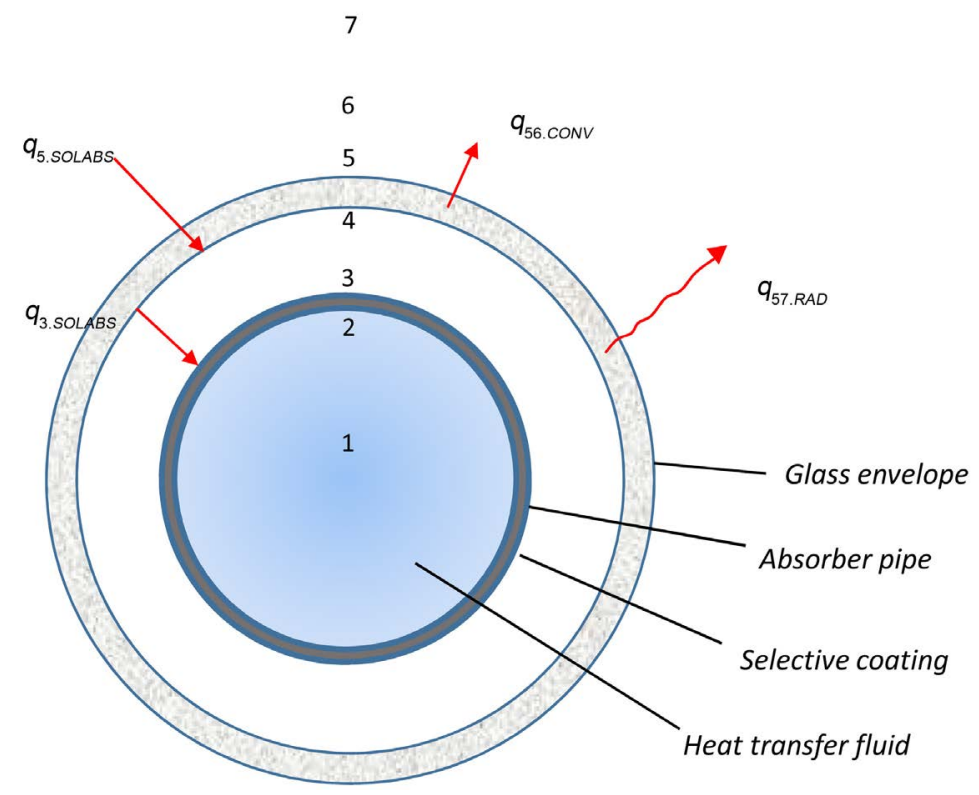

Figure 8. Diagram of heat transfer model.

solar collectors, each SCA was discretized into receiver components. The inputs were the local DNI, and ambient temperature conditions. The cosine corrected DNI was calculated from the collector incidence angle in the manner presented by Marion and Dobbs for a one-axis tracker [36]. The DNI and temperature were used along with the input parameters to determine a new temperature for Sections 6 and 7:

$$
T_{6}=\frac{\left(q_{3, \text { SOLABS }}+2 q_{5, \text { SOLABS }}-q_{56, \mathrm{CONV}}-q_{57, \text { RAD }}\right) L}{\dot{m}_{S L} c_{p 5}}+T_{5}
$$




$$
T_{7}=\frac{\left(q_{3, S O L A B S}+2 q_{5, S O L A B S}-q_{56, C O N V}-q_{57, R A D}\right) L}{\dot{m}_{S L} c_{p, W F 6}}+T_{6}
$$

Here, the radiative heat flux into the glass envelop (point 5 in Figure 8) and into the HTF (point 3), $q_{\text {SOLABS }}$, is found from [37],

$$
\begin{gathered}
q_{3, \text { SOLABS }}=q_{s i} \eta_{A B S} \alpha_{A B S} \\
q_{5, \text { SOLABS }}=q_{S i} \eta_{E N V} \alpha_{E N V}
\end{gathered}
$$

where $\alpha_{A B S}$ is the absorptivity of the HCE selective coating, $\eta_{E N V}$ is the effective optical efficiency of the HCE envelope and $\alpha_{E N V}$ is the absorptivity of the HCE glass envelope, all of which are input parameters. The effective optical efficiency of the HCE selective coating, $\eta_{A B S}$, is taken as:

$$
\eta_{A B S}=0.97 \eta_{E N V}
$$

The incident radiation per unit length, $q_{s i}$, to the HCE is:

$$
q_{s i}=\frac{D N I * A}{L}
$$

The heat loss of the element due to convection, $q_{56, C O N V}$, is found from [35]:

$$
q_{56, \mathrm{CONV}}=h_{56} D_{5} \pi\left(T_{5}-T_{A M B}\right)
$$

where the convective heat transfer coefficient, $h_{56}$, is a function of the Nusselt number, $N u_{D 5}$, and the thermal conductance of air, $K_{56}$ :

$$
\begin{gathered}
h_{56}=\frac{K_{56} N u_{D 5}}{D_{5}} \\
N u_{D 5}=\left[\frac{0.6+\left(0.387 R a_{D 5}^{\frac{1}{6}}\right)}{\left(1+\left(\frac{0.599}{P r_{56}}\right)^{\frac{9}{16}}\right)^{\frac{8}{27}}}\right]^{2} \\
\operatorname{Pr}_{56}=\frac{v_{56}}{\alpha_{56}}
\end{gathered}
$$

where $R a_{D 5}$ is the Rayleigh number and $P r_{56}$ is the Prandtl number,

$$
R a_{D 5}=\frac{9.81 \beta\left(T_{5, S T}-T_{A M B}\right) D_{5}^{3}}{\alpha_{56} v_{56}}
$$

And,

$$
\begin{gathered}
T_{56}=\frac{T_{5, S T}+T_{a m b}}{2} \\
\beta=\frac{1}{T_{5, S T}+273}
\end{gathered}
$$

Finally, the radiative heat loss is 


$$
q_{57, R A D}=\sigma \pi D_{5} \varepsilon_{5}\left(\left(T_{5}+273\right)^{4}-\left(T_{7}+273\right)^{4}\right)
$$

where $T_{7}$, the effective sky temperature is estimated as:

$$
T_{7, S T}=T_{A M B}-8
$$

\subsection{ORC}

The ORC was modeled utilizing the four basic sections of a Rankine cycle (as shown in Figure 2), beginning with the boiler/evaporator [38]. Heat input, $Q_{i n}$, raises the temperature of the HTF until reaching a saturated vapor condition, $T_{1}$, based on an assumed boiler efficiency, $\eta_{B}$, and initial mass flowrate of the WF, $\dot{m}_{O R C}$. The boiler is modeled such that all power cycle heat addition (preheating, evaporation, and superheating) takes place in a single adiabatic counter-flow heat exchanger, modeled as an isobaric process. The pressure, $P_{\text {high }}$, is a parameter based on the WF selected and produced as an outlet of the pump in Section 4. The pump can be either variable speed, as in this system, to match the heat input and produce the desired high pressure, or fixed speed so that the mechanical work, and thus $\Delta P$, remains fixed. The enthalpy, $h_{1}$, and entropy, $s_{1}$, are fixed based on the pressure and temperature state.

$$
\begin{gathered}
P_{1}=P_{h i g h} \\
T_{1}=\eta_{B} \frac{Q_{\text {in }}}{\dot{m}_{\text {ORC }} c_{p, H T F}}+T_{4} \\
h_{1}=h_{@ P_{1} \& T_{1}} \\
s_{1}=s_{@ P_{1} \& T_{1}}
\end{gathered}
$$

In Section 2, the vapor undergoes isentropic expansion, producing mechanical work [38]. A turbine efficiency, $\eta_{t u r b}$, is utilized to determine the quantity of mechanical work extracted, $\dot{W}_{\text {turb }}$, and the pressure drop across the expansion. The generator efficiency, $\eta_{g e n}$, then gives the electric energy produced by the system, $\dot{W}_{g e n}$. The temperature leaving the expander is determined from the entropy entering the expander and the pressure downstream of the turbine, following the constant entropy process. In an ORC, the low pressure, $P_{\text {low }}$, is generally just above ambient, removing the need for additional equipment. The enthalpy leaving the expander is found from the ideal enthalpy and the turbine efficiency.

$$
\begin{gathered}
P_{2}=P_{\text {low }} \\
s_{2}=s_{1} \\
T_{2}=T_{@ P_{2} \& s_{2}} \\
h_{2, \text { ideal }}=h_{@ P_{2} \& s_{2}} \\
h_{2}=h_{1}-\eta_{\text {turb }}\left(h_{1}-h_{2, \text { ideal }}\right) \\
\dot{W}_{\text {turb }}=-\dot{m}\left(h_{2}-h_{1}\right)
\end{gathered}
$$




$$
\dot{W}_{\text {gen }}=\dot{W}_{\text {turb }} \eta_{\text {gen }}
$$

Section 3 is isobaric heat removal from the system by heat transfer from the low-pressure WF vapor to the cooling water in an adiabatic counter-flow heat exchanger [38]. The WF exit is assumed to be a saturated liquid at a temperature matching the cooling water temperature exiting the condenser. The specific volume, $v_{4}$, is determined by the saturated conditions of the WF at the given pressure and temperature.

$$
\begin{gathered}
P_{3}=P_{2} \\
T_{3}=T_{10} \\
h_{3}=h_{@ P_{3} \& T_{3}} \\
s_{3}=s_{@ P_{3} \& T_{3}} \\
v_{4}=v_{@ P_{3} \& T_{3}}
\end{gathered}
$$

In Section 4, the WF undergoes isentropic compression (addition of mechanical work) that raises the pressure of the WF to the desired working pressure of the boiler, $P_{\text {high }}$ [38]. The quantity of mechanical work is based on the enthalpy and a pumping efficiency, $\eta_{P}$.

$$
\begin{gathered}
s_{4}=s_{3} \\
P_{4}=P_{h i g h} \\
v_{4}=v_{\text {sat } @ P_{4}} \\
h_{4, \text { ideal }}=h_{3}+v_{3}\left(P_{1}-P_{2}\right) \\
h_{4}=h_{3}+\frac{h_{4, \text { ideal }}-h_{3}}{\eta_{\text {pump }}} \\
T_{4}=T_{@ s_{4} \& h_{4}} \\
\dot{W}_{\text {pump }}=-\dot{m}\left(h_{1}-h_{4}\right)
\end{gathered}
$$

\subsection{Cooling Loop}

The methodology used to model the process in the cooling loop is divided into two portions. The first section is the outlet of the cooling tower. In order to calculate the temperature of the cooling water exiting the cooling tower, $T_{9}$, the wet bulb temperature, $T_{w b}$ and the efficiency of the cooling tower, $\eta_{C T}$ are used. The wet bulb temperature is the lower temperature limit of the outlet water from a cooling tower. To calculate the wet bulb temperature, an empirical model is employed [39], as shown in Equation (42). Humidity and ambient temperature inputs generate a wet bulb temperature with a mean error of 0.0052 degrees ${ }^{\circ} \mathrm{C}$. The second portion determines the water temperature exiting the condenser, $T_{10}$, by assuming the heat removal from the WF is constant. The following models are used to calculate the sections in the cooling loop. 


$$
\begin{gathered}
T_{w b}=T_{a m b} * \operatorname{atan}(0.151977 * \sqrt{H U M+8.313659}) \\
+\operatorname{atan}\left(T_{a m b}+H U M\right)-\operatorname{atan}(H U M-1.676331) \\
+0.00391838(H U M)^{\frac{3}{2}} * \operatorname{atan}(0.023101 * H U M)-4.68035 \\
T_{9}=T_{10}-\eta_{C T}\left(T_{10}-T_{w b}\right) \\
T_{10}=\frac{Q_{o u t}}{\dot{m}_{C L} c_{p w}}+T_{9}
\end{gathered}
$$

\subsection{Experimental Data}

Solar radiation measurements were taken onsite by a weather station consisting of a Kipp \& Zonen SOLYS 2 Sun Tracker with CHP 1 pyreheliometer and CMP10 Pyranometers. The SOLYS 2 sun tracker provides fully automated year-round two-axis tracking of the position of the Sun with a pointing accuracy of less than 0.1 degrees. It has Baseline Surface Radiation Network (BSRN) levels of performance and reliability. Mounted on the SOLYS 2 are a CHP1 pyrheliometer which fully complies with the most current ISO and WMO performance criteria for First Class Normal Incidence pyrheliometer with a World Radiometric Reference (WRR) calibration certificate. For a first class pyrheliometer, the WMO limits maximum errors to $3 \%$ for hourly radiation totals. In the daily total an error of $2 \%$ is expected, because some response variations cancel each other out for longer integration periods. Kipp \& Zonen, however anticipates maximum uncertainty of $2 \%$ for hourly totals and $1 \%$ for daily totals for the CHP 1 pyrheliometer [40]. The CHP1, installed in July of 2013, provides a measure of the direct normal irradiance (DNI), or the direct beam portion of the solar spectrum which can be concentrated for conversion to thermal energy. The CMP10 Secondary Standard pyranometer was then installed in November of 2014 to measure the global horizontal irradiance, a measure of the total (diffuse + direct) radiation reaching the surface. For a "High Quality" pyranometer, the WMO expects maximum uncertainty error for the hourly radiation totals of 3\% and errors in daily totals less than 2\% [41]. Also installed in December, 2014 is a second CMP10 pyranometer to give a direct measurement of the diffuse potion of the spectrum. A Campbell Scientific CR1000 provides data logging and wireless data streaming to the nearby Cleco Alternative Energy Center. Until now, the closest proximity measured data available for local solar resource measurement and prediction was in Lake Charles, Louisiana, about 100 miles to the west. For measurement of the ambient conditions, a Davis Vantage Vue wireless meteorological weather station is also located within the START Lab. The Vantage Vue provides all the necessary meteorological data for proper evaluation of the solar technologies on site and wirelessly steams and logs the data within the Cleco Alternative Energy Center. Data including ambient temperature, humidity, barometric pressure, wind speed, wind direction, rainfall, dew point etc. are constantly monitored and recorded. This method of collecting and combining meteorological data from a weather station with DNI from a tracking pyreheli- 
ometer and DHI and GHI from pyranometers is an industry standard.

\section{Results and Model Validation}

The model was validated using data collected on several days throughout the years of 2015, 2016, and 2017 in order to have representation from each season affected by the local climate. The UL Lafayette START Lab is located in Crowley, Louisiana, about 20 miles west of Lafayette, with a latitude of $30^{\circ} 13^{\prime} 27^{\prime \prime} \mathrm{N}$. The parabolic solar troughs are oriented in a north-south configuration, while tracking the sun from east to west. Measured inputs of local DNI, ambient temperature, and humidity were input into the model and the simulated results were compared to measured values of the system temperatures, thermal energy, electric power, and system efficiency. Temperatures were measured at the inlet and outlet of the collector field loop, the ORC evaporator, condenser, and turbine. A constant flow rate of $97.5 \mathrm{gpm}$, and $220 \mathrm{gpm}$ were assumed for the Solar Loop and Cooling loop, respectively.

\subsection{Solar Loop Model Performance}

Data were generated for the thermal output of each SCA, both in terms of thermal energy (kWth) and in temperature rise $(\Delta T)$ and plotted versus the DNI over the course of a summer day and a winter day. Both experimental and modeled data were recorded in Figure 9 and Figure 10. There is good agreement in trend with some deviation in the summer data from the expected linearity of the output. The modeled data also agrees well with an internal model of the LAT generated by $3 \mathrm{M}$ Corp. (Figure 11) with Incidence Angle Modifier (IAM) effects fully characterized and included. Negative deviation from the model is expected in both seasons due to ideal assumptions of specularity and tracking error. The

Delta T vs. DNI - 1x6 LAT (97 GPM flow rate)

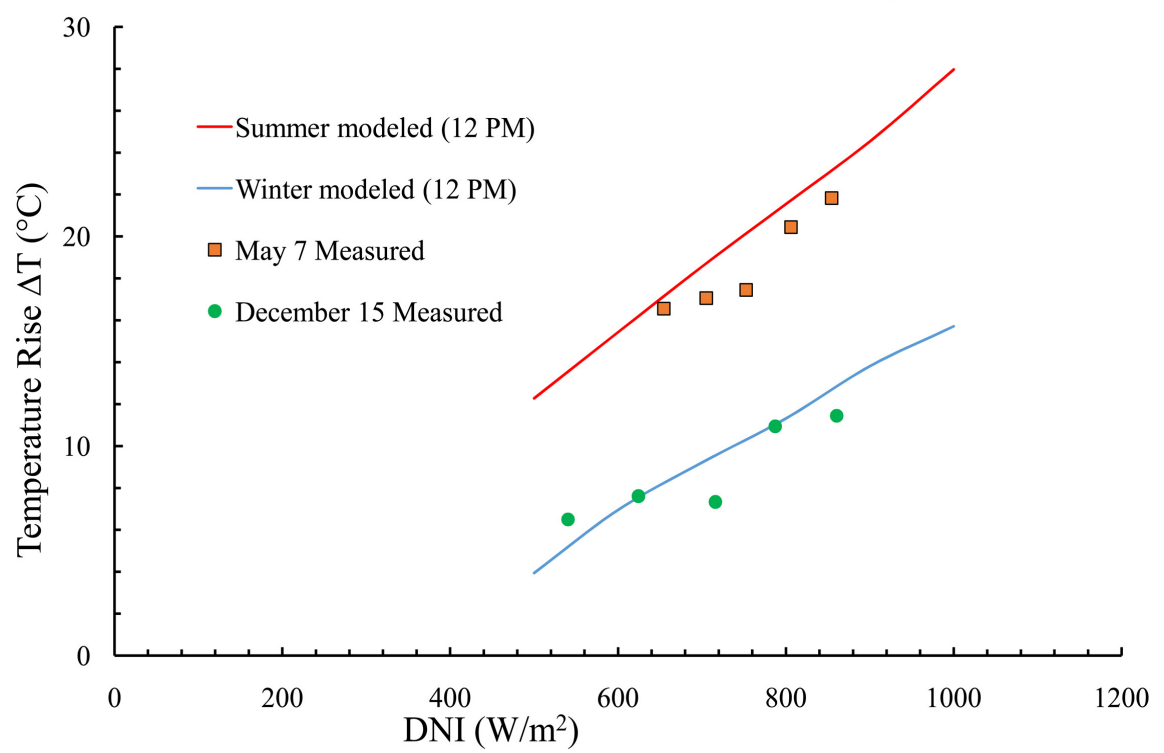

Figure 9. Modeled and experimental thermal output from one SCA. 


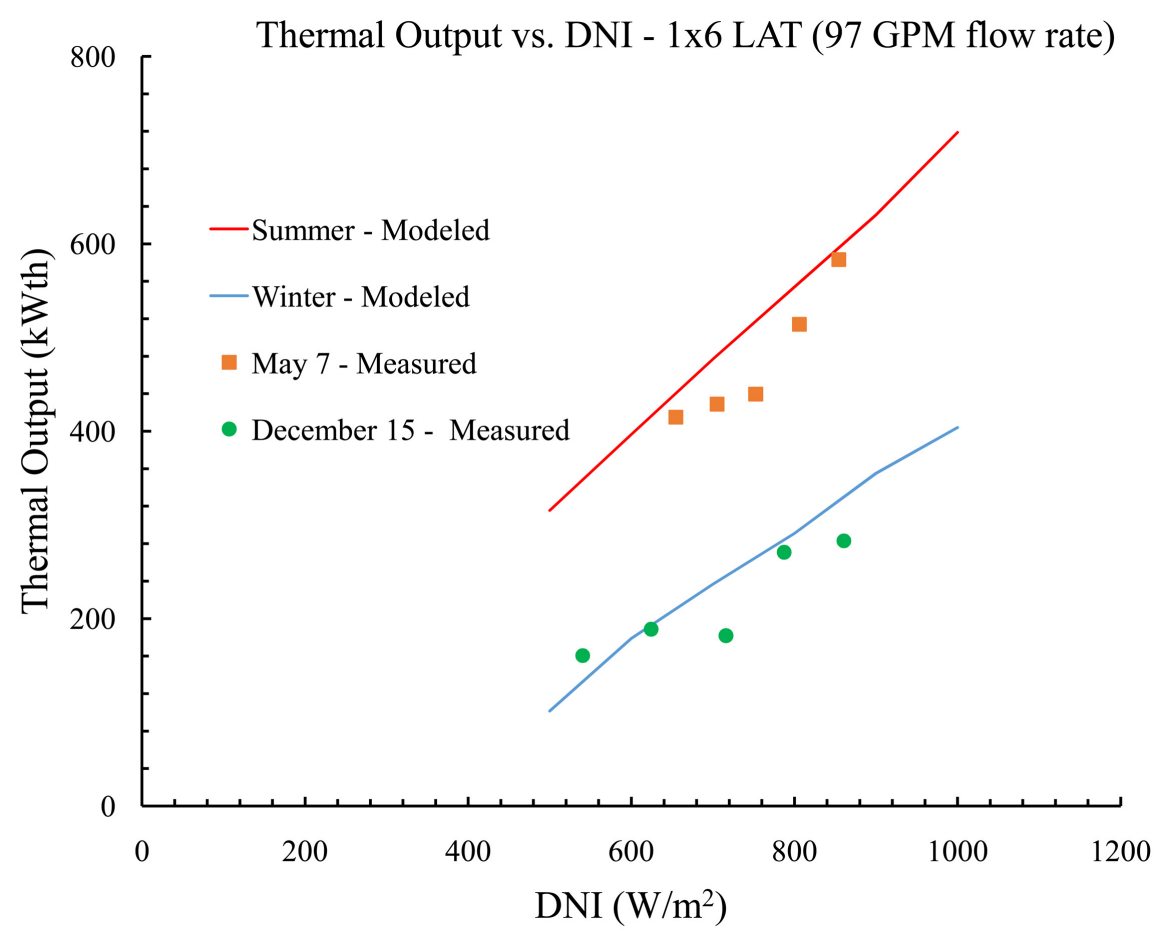

Figure 10. Modeled and experimental temperature rise from one SCA.

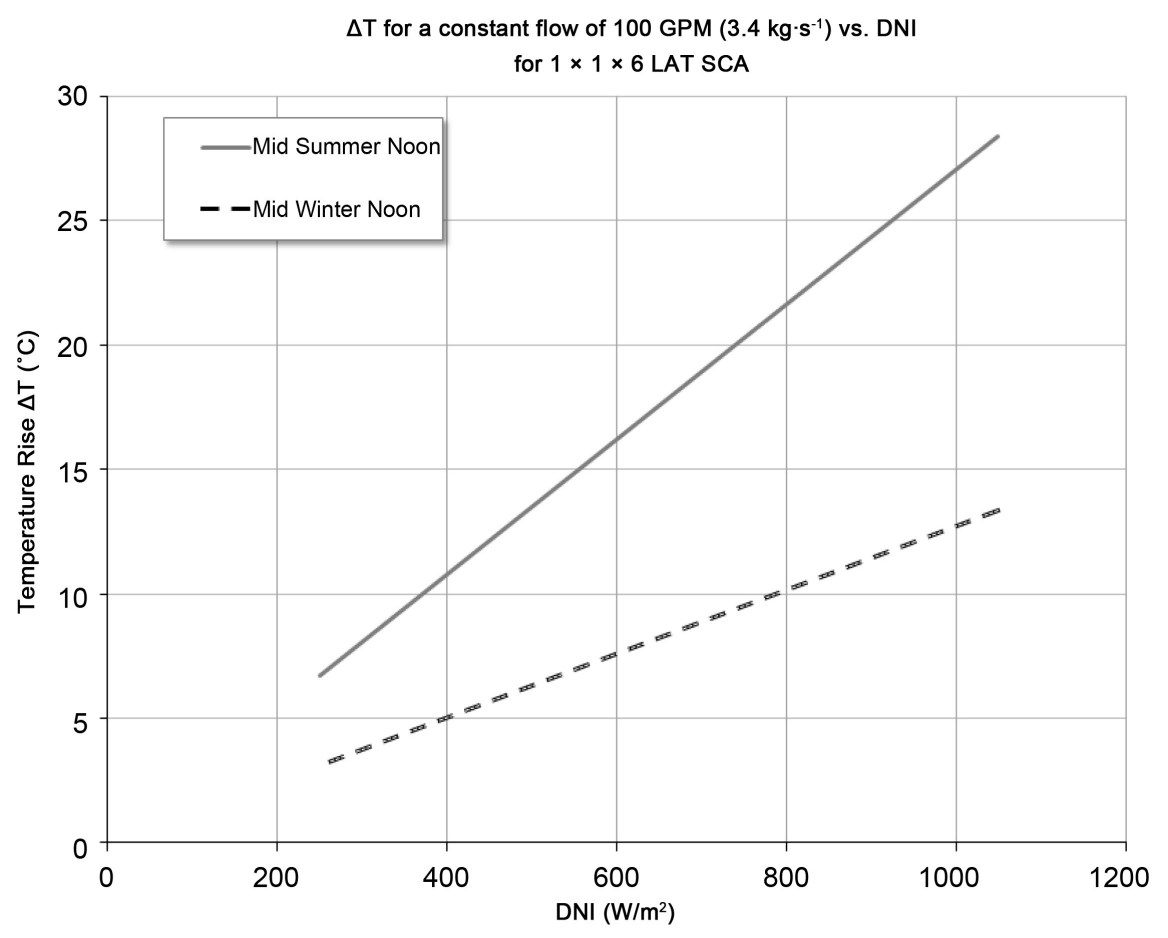

Figure 11. 3M model of temperature rise of one SCA.

greater deviation in the winter data is accounted for by larger radiative losses than accounted for in the model due to uninsulated piping in the balance of plant. In addition, IAMs for the site are not included which will be more pronounced in the winter season. 
The collector model was then used to predict the collector thermal efficiency over a range of irradiance and HTF flowrate values (Figure 12). The collector efficiency was calculated from the ratio of the thermal energy produced and the thermal energy into the system:

$$
\eta_{\text {collector }}=\frac{Q_{\text {in, coll }}}{D N I * A}
$$

where

$$
Q_{\text {in, coll }}=\dot{m}_{H T F} C_{p} \Delta T
$$

The curves are presented in Figure. The efficiency drops as flow rate increases, which reduces the residence time for heat transfer. The efficiency also increases as DNI increases, due to the increase in intensity of the energy into the system. The full data from a single summer day and a single winter data are presented in Figure 13 and Figure 14. The modeled and measured $\Delta T$ are plotted versus the actual DNI for the day investigated. The summer day shows good correlation where IAM effects are minimal, and the tracking error effects are lower relative to the winter day where the collectors must travel at a higher rotational rate through the tracking arc. The difference is significant in the winter day where IAM effects become dominant. Upon review, discrepancies existed between the measured temperature exiting the solar collectors, and the simulated values $T_{7}$. In order to investigate the discrepancy, the simulated temperature, measured temperature, and DNI were plotted. As shown in Figure 14, the measured DNI and the simulated temperature correlate with each other, however transient effects create errors due to changes in DNI not tracking with measured temperature change due to thermal inertia in the system.

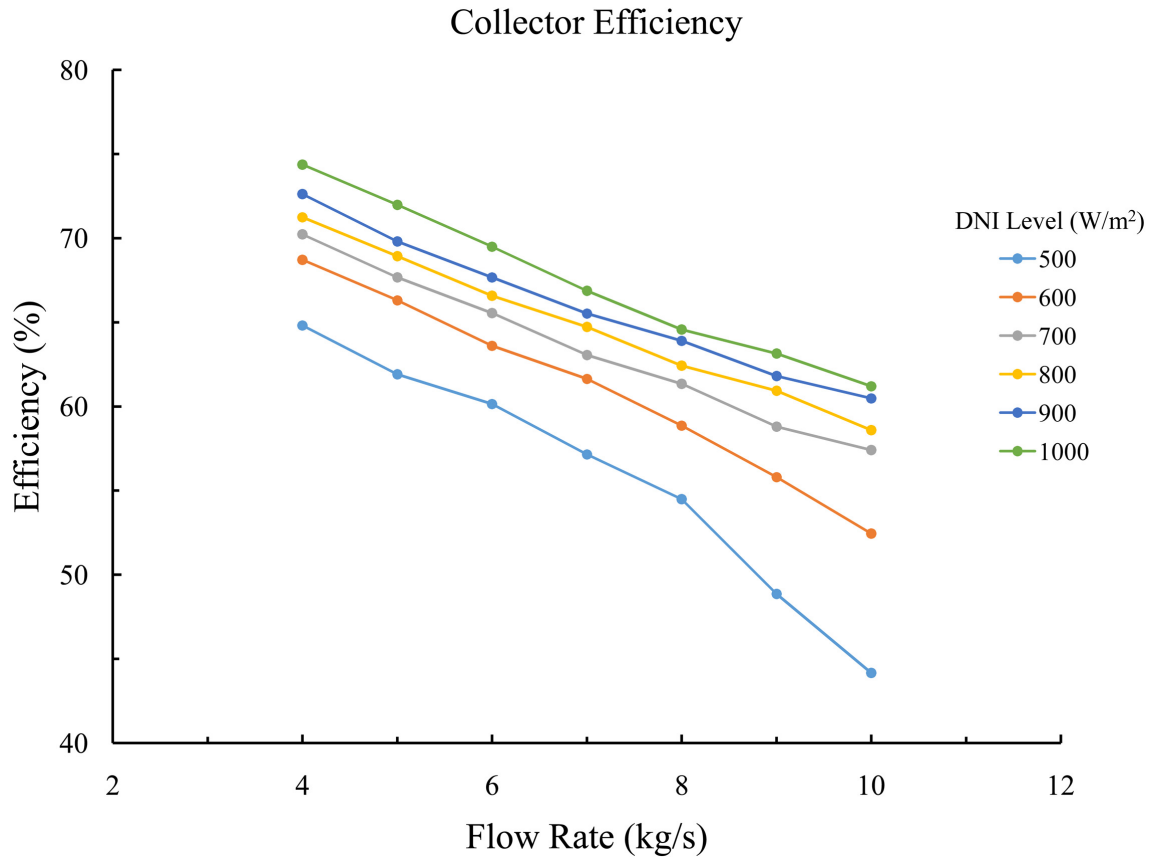

Figure 12. Modeled efficiency curves of LAT. 


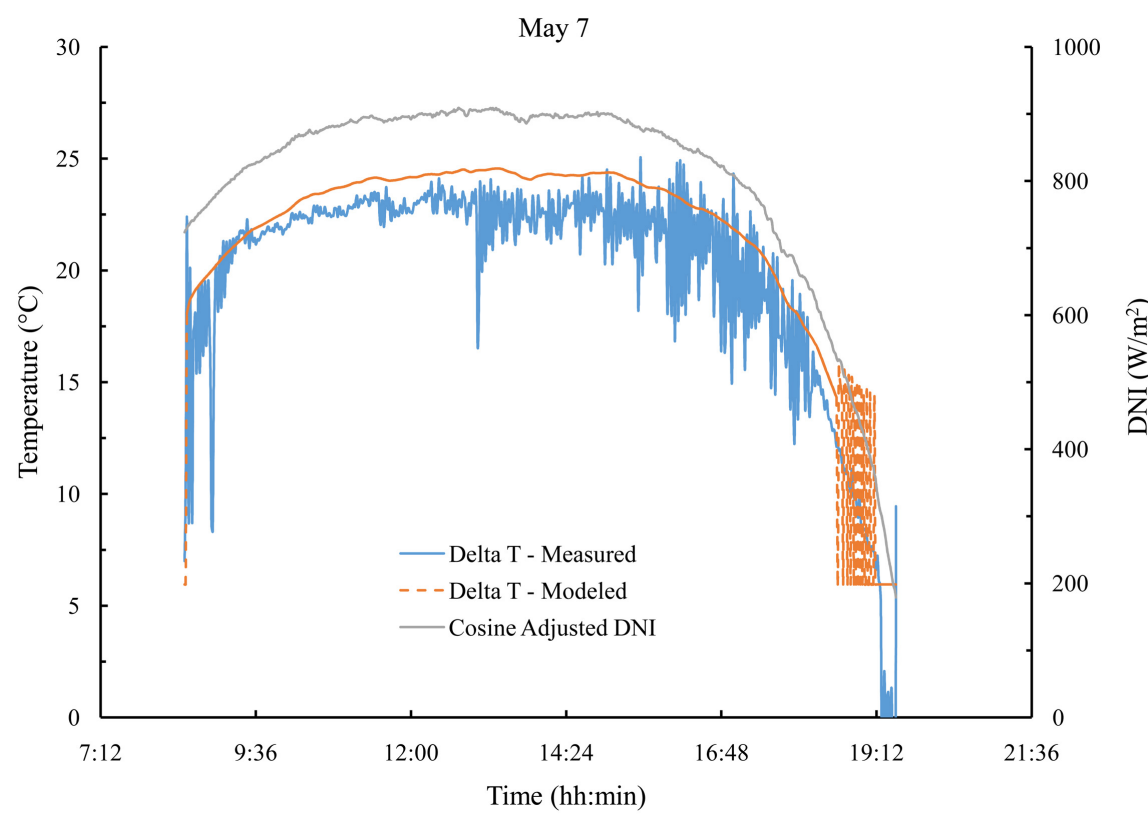

Figure 13. Modeled and measured delta T for a summer day.

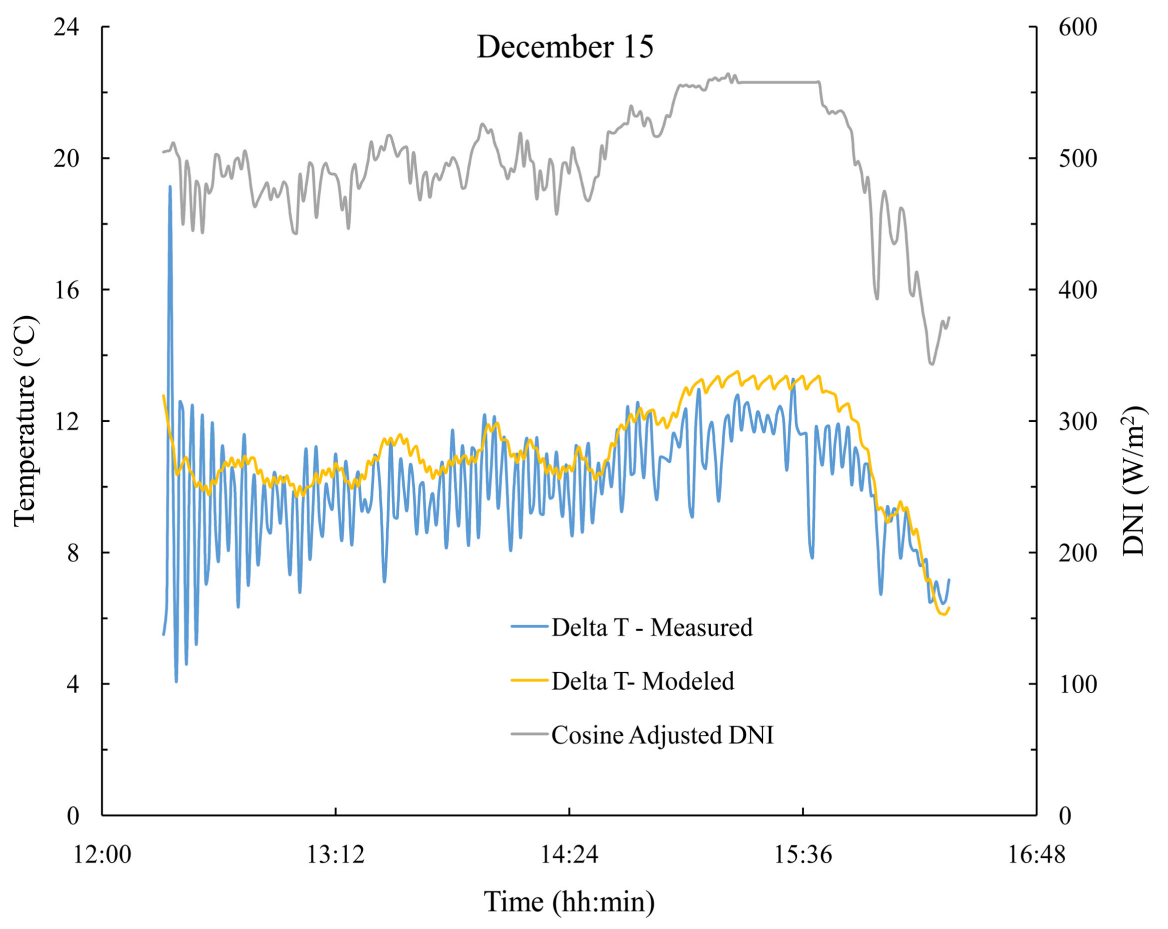

Figure 14. Modeled and measured delta $\mathrm{T}$ for a winter day.

\subsection{ORC Model Performance}

The ORC model performance can be seen visually by plotting the HTF temperature exiting the boiler/evaporator and returning to the solar field, a measure of the heat gain into the system. The evaporator model performed well over the range of DNI values for both winter and summer days (Figure 15 and Figure 16). Additionally, the WF temperature correlated well to the measured data for 


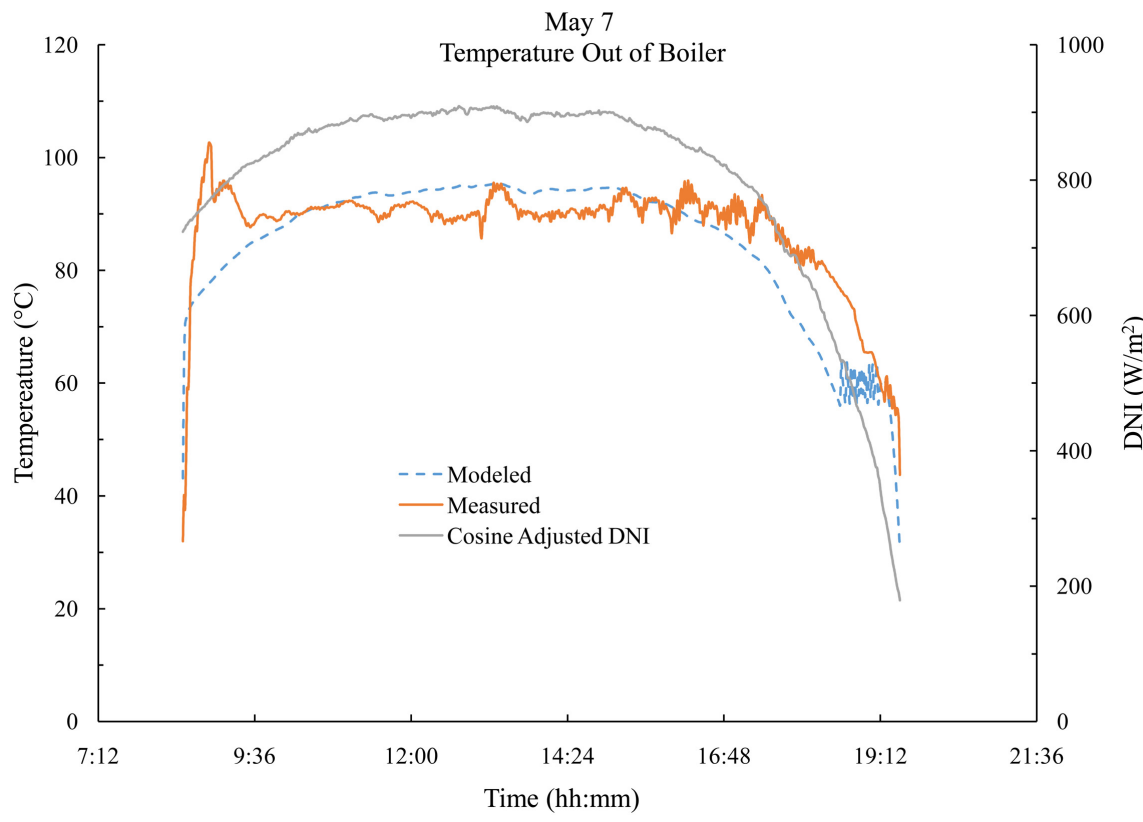

Figure 15. HTF temperature exiting boiler, summer.

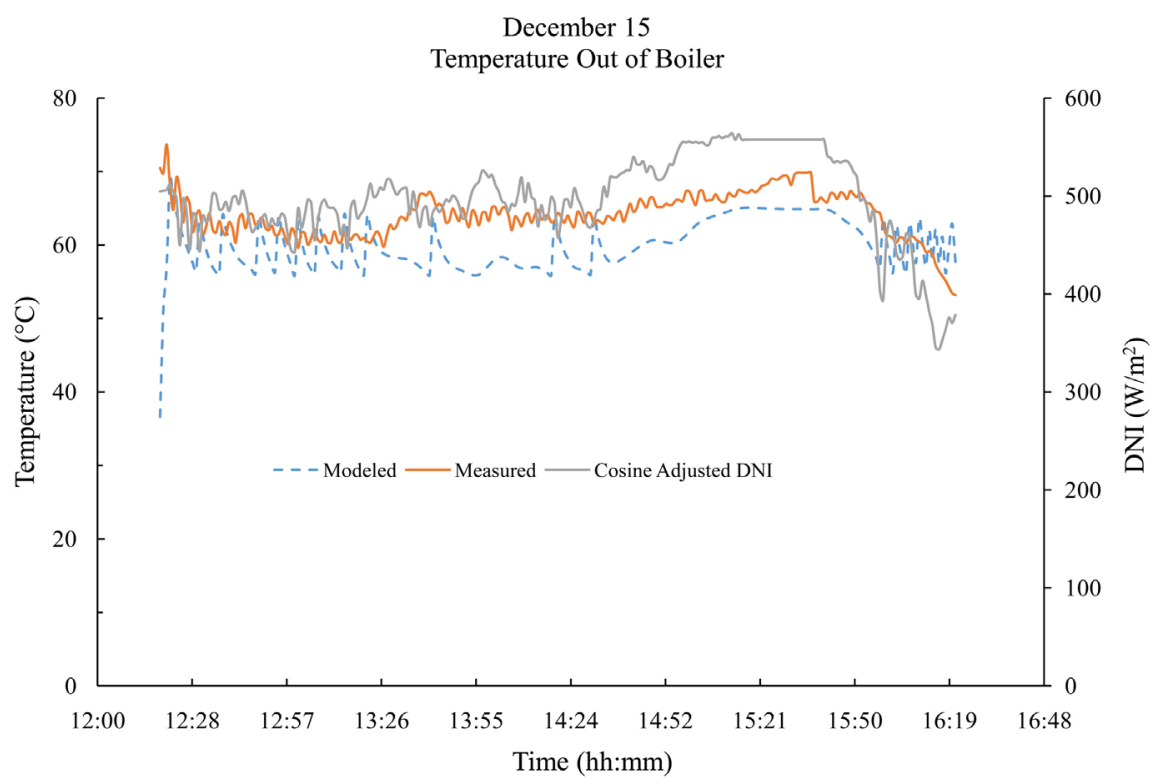

Figure 16. HTF temperature exiting boiler, winter.

varying conditions (Figure 17). There were isolated drops in the modeled temperature not seen in the measured data due to thermal inertia in the physical system. The cooling water entering and exiting the condenser also show small levels of uncertainty (Figures 18-20). The cooling water model developed several peaks that again were smoothed by thermal inertia in the physical system.

\subsection{System Performance}

The collector and power block models together produce system-level outputs and efficiencies. Values for the measured power, simulated power, and DNI are 


\section{ORC Evaporator WF Outlet Temperature}

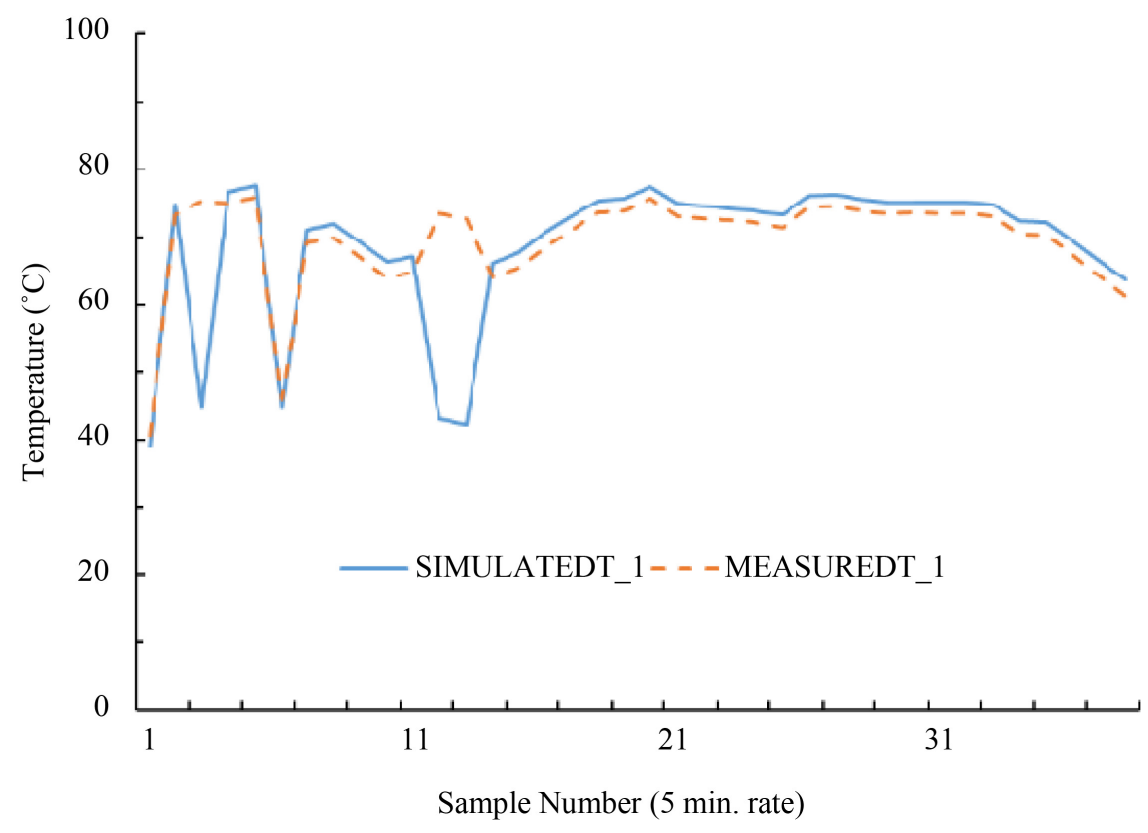

Figure 17. Boiler/Evaporator outlet WF temperature.

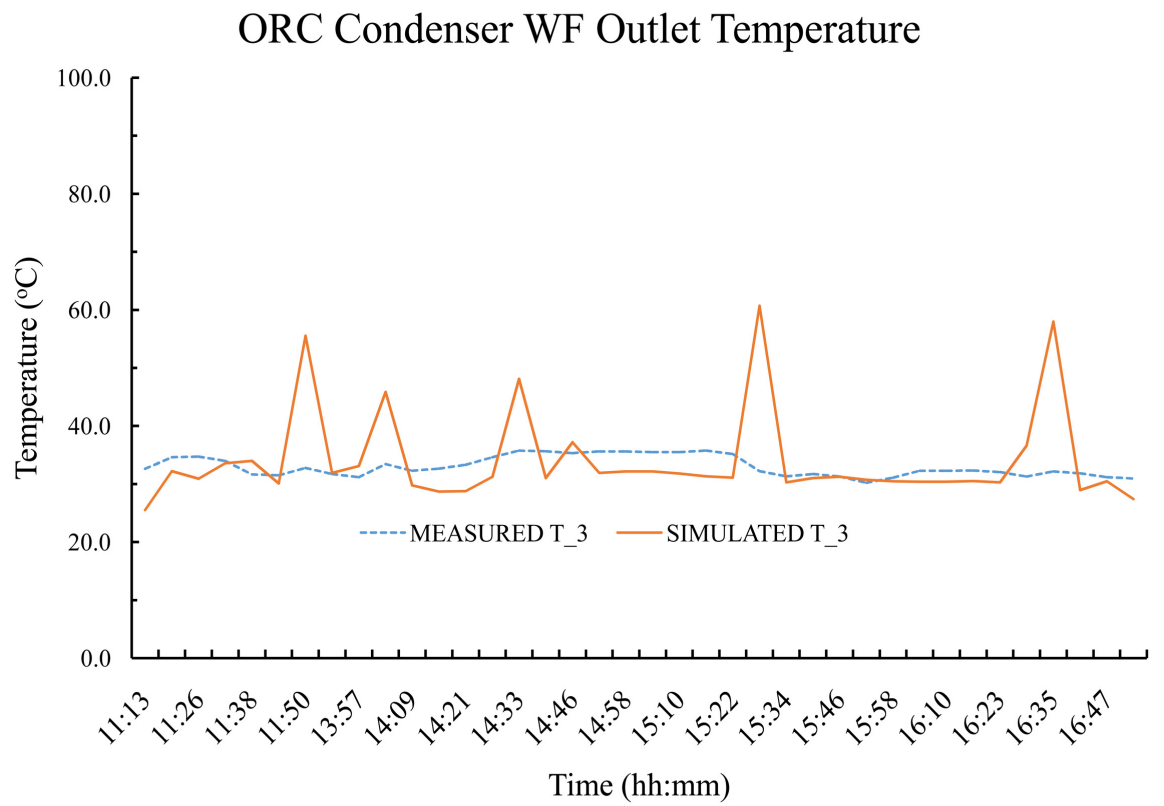

Figure 18. Condenser WF outlet temperature.

plotted in Figure 21 while system efficiencies and percent error of efficiencies are plotted in Figure 22 and Figure 23. As shown, the simulated power produced is proportional to the DNI, however, the measured power does not correlate perfectly with the measured DNI. It can be seen that despite cumulative error in the solar loop and power block that the power error remains around 10 percent. The bulk of the uncertainty is in the collector loop, while the simple Rankine cycle model performs relatively well. Should storage or a thermal buffer 


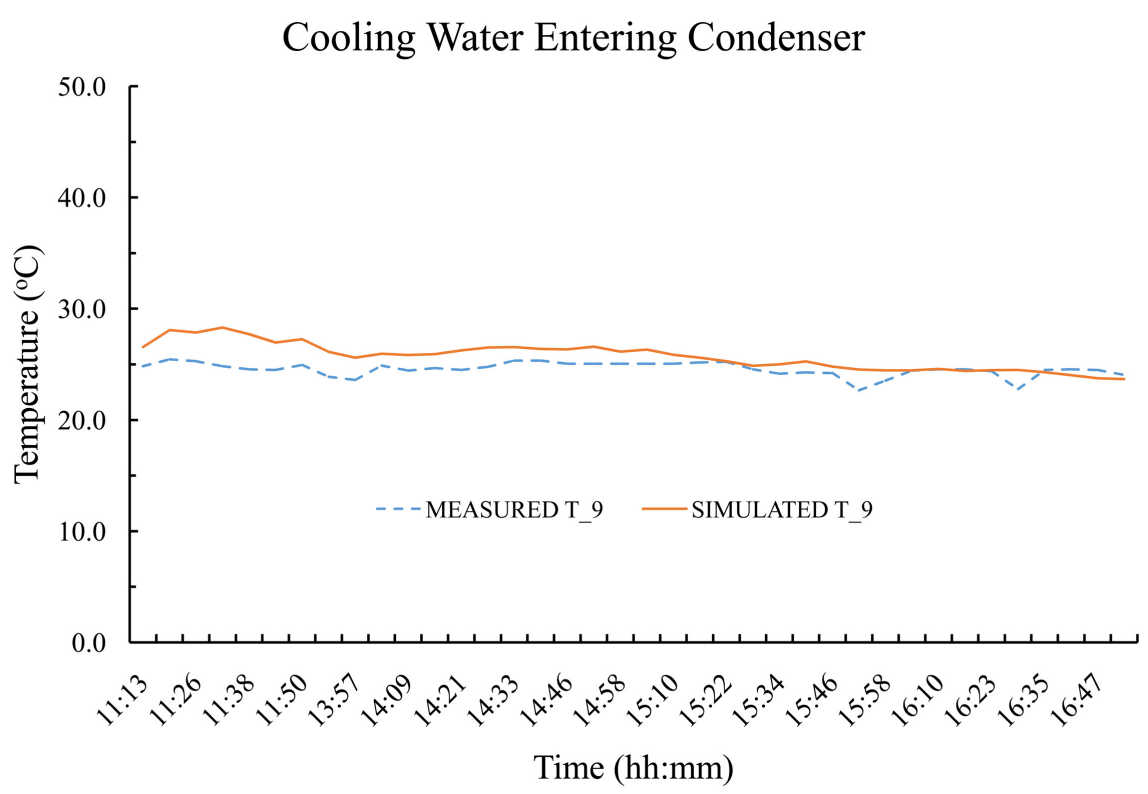

Figure 19. Condenser inlet temperature results.

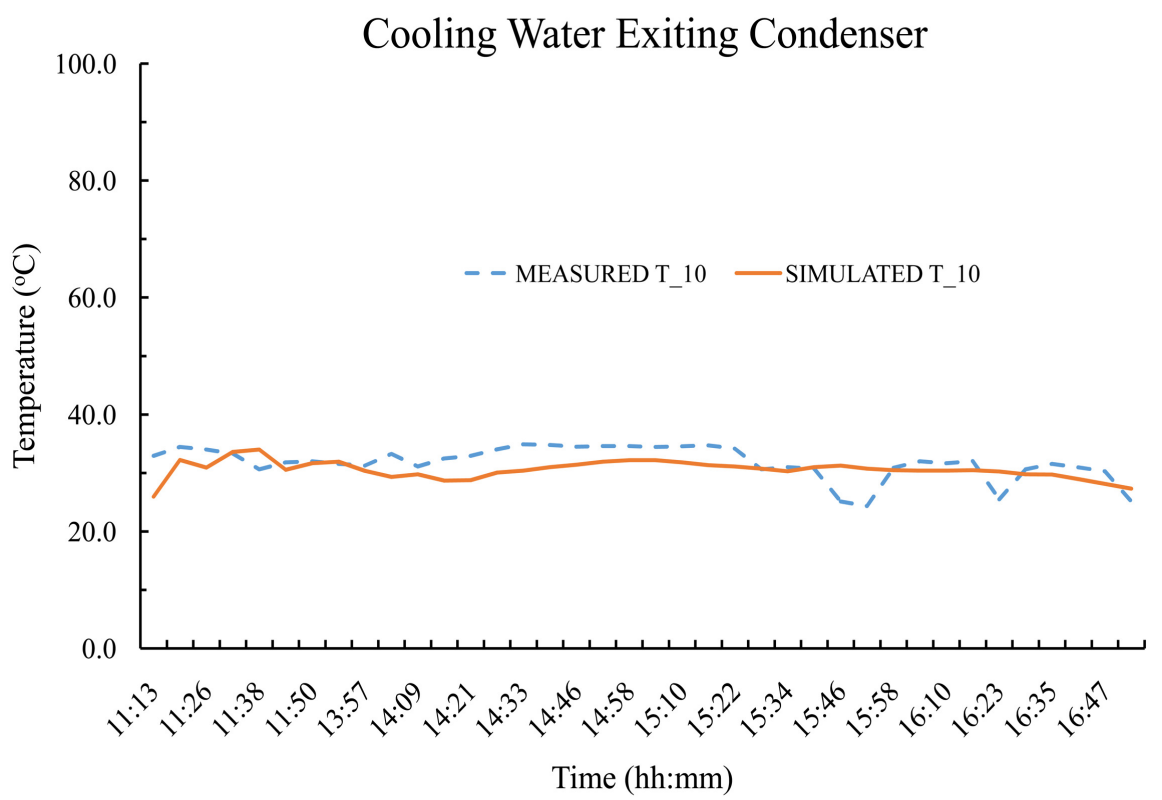

Figure 20. Condenser outlet temperature results.

be integrated into the solar loop, this would smooth the energy input into the power block and the power block model would have a further reduction in error.

The results of the system analysis are summarized in Table 3. The model error, in terms of power produced, averages about 11 percent in spring and summer and grows to about 15 percent in winter, largely due to the contributions of error in the solar field mentioned above (IAM, heat losses, etc.).

\subsection{Annual Predictive Performance}

Based on the validated model, the annual performance of a theoretical system 


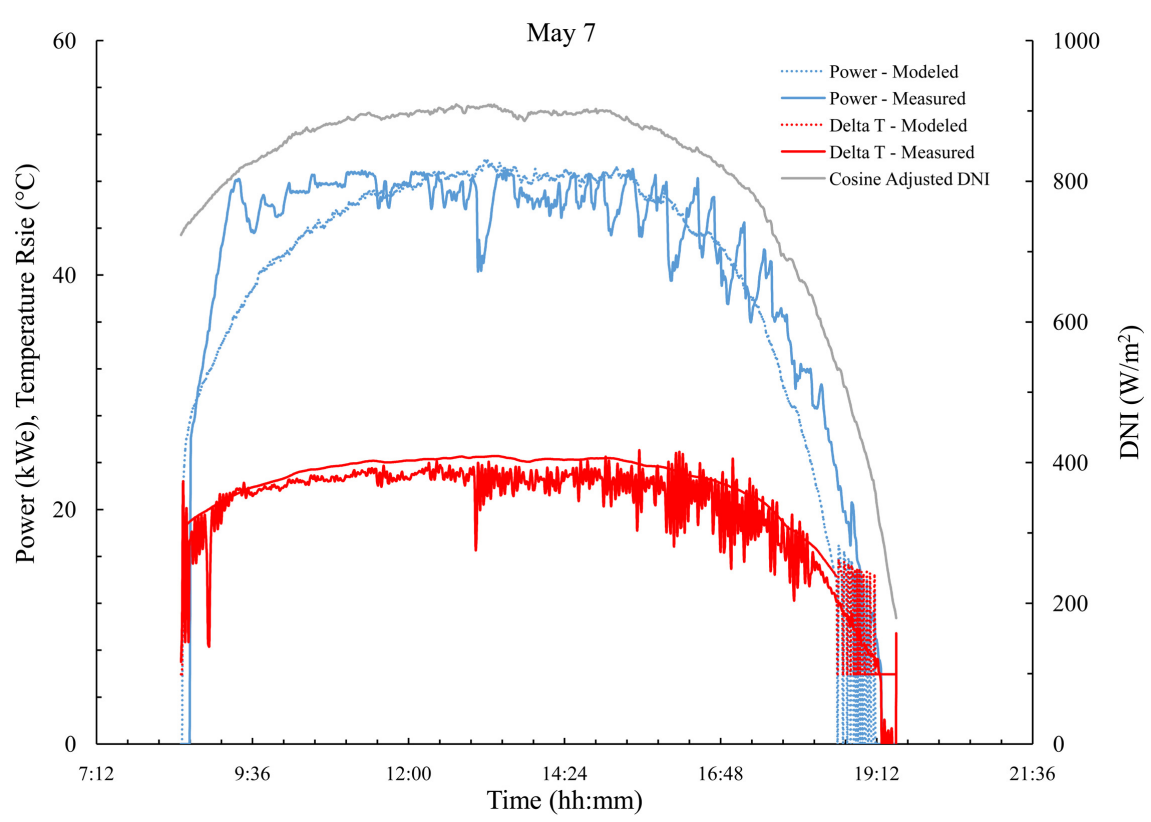

Figure 21. System power output, collector temperature rise versus modeled data, summer.

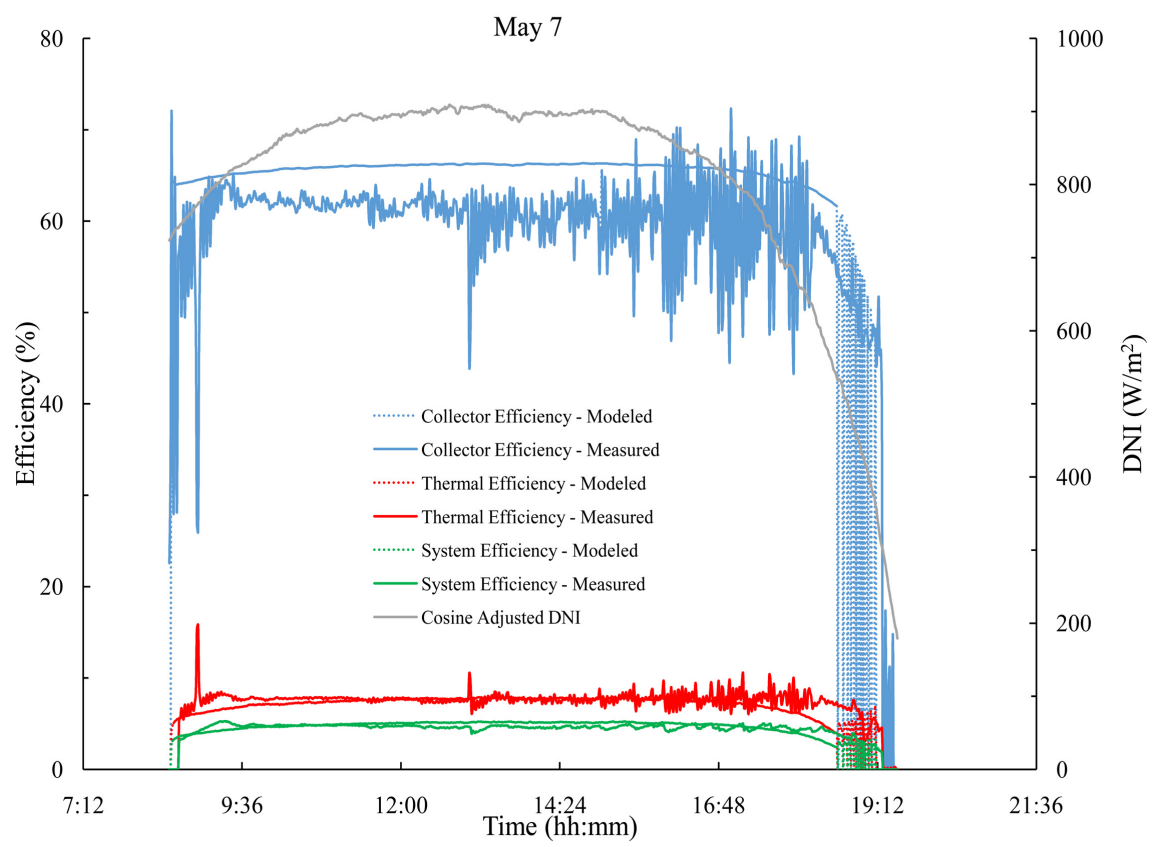

Figure 22. System thermal and electric efficiency versus modeled data, summer.

could be modeled within the uncertainties found above. Typical meteorological year (TMY) data from the National Solar Radiation Database (NSRDB) was utilized as an input to the model with daily and monthly thermal outputs from the solar field and electric outputs from the power plant tabulated. The total thermal output was predicted to be $919 \mathrm{MWhr}$-thermal per annum, while the total electric output was predicted to be $48 \mathrm{MWhr}$-electric, an effective annual system efficiency. The plant was predicted to operate on 169 days based on the start-up 


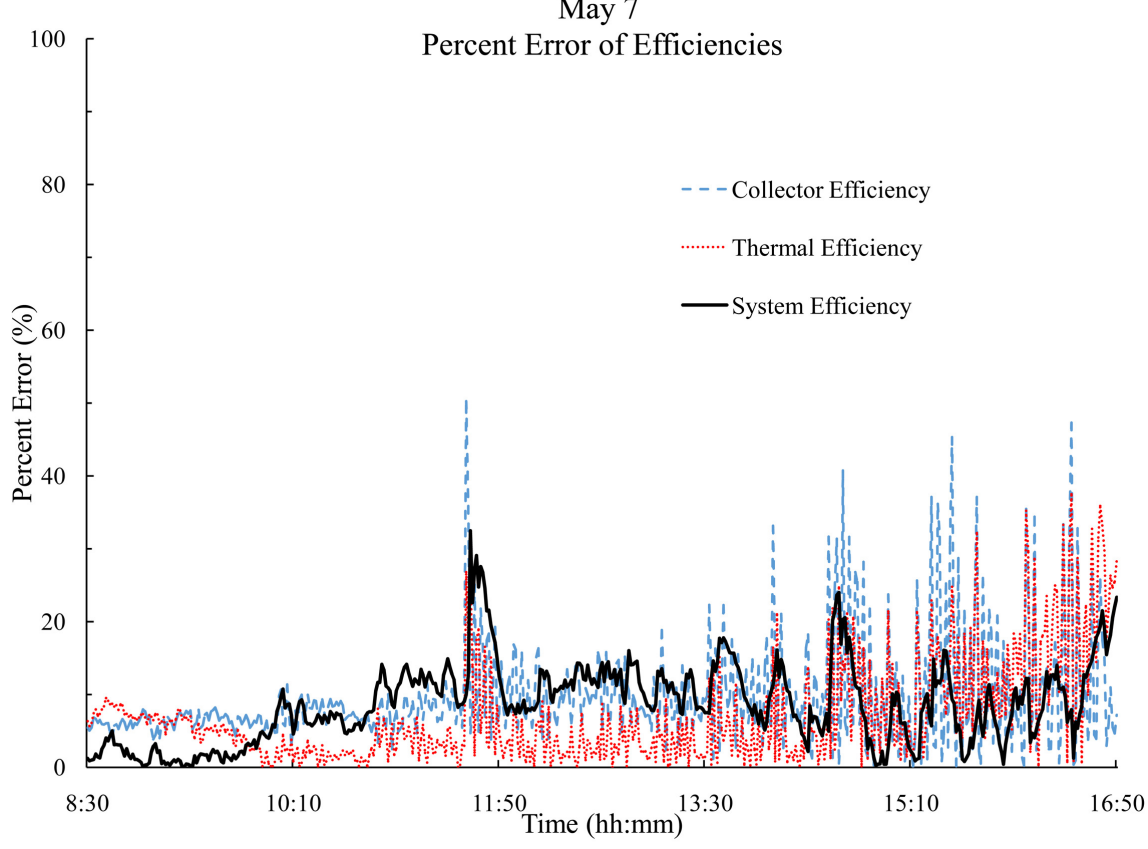

Figure 23. Percent error of efficiencies between model and experimental data, summer.

Table 3. Model power and efficiency uncertainty.

\begin{tabular}{ccccccc}
\hline \multicolumn{7}{c}{ Model Error (\% Difference) } \\
\hline & Spring & $\begin{array}{c}\text { Stnd. } \\
\text { Dev. }\end{array}$ & Summer & $\begin{array}{c}\text { Stnd. } \\
\text { Dev. }\end{array}$ & Winter & $\begin{array}{c}\text { Stnd. } \\
\text { Dev. }\end{array}$ \\
\hline $\begin{array}{c}\text { Collector Thermal } \\
\text { Power (kWth) }\end{array}$ & 11.65 & 5.23 & 10.46 & 37.05 & 13.8 & 25.5 \\
$\begin{array}{c}\text { Power Block Electric } \\
\text { Power (kWe) }\end{array}$ & 10.3 & 5.06 & 11.46 & 3.90 & 15.34 & 4.26 \\
$\begin{array}{c}\text { Collector Efficiency } \\
\text { System Efficiency }\end{array}$ & 8.3 & 15.34 & 9.74 & 4.63 & 13.4 & 4.7 \\
\hline
\end{tabular}

criteria. Figure 24 and Figure 25 give the predicted daily thermal and electric outputs from the plant, respectively. The annual validation will be updated as year-long operational data becomes available. When utilizing the same input DNI, the model compared well to the GSF LAT specific model an annual difference in collector output of $8.6 \%$ (Figure 26 and Figure 27). The annual collector efficiency was calculated based on the total energy produced and the annual insolation, resulting in a $62.4 \%$ efficiency. The annual system efficiency was then found to be $3.2 \%$ on an insolation-to-electric basis (Figure 28).

\section{Discussion and Conclusions}

A numerical model of a small-scale parabolic trough organic Rankine cycle power plant has been presented with operational data for validation. A simplified model, with relatively few required parametric data for operation, can be useful in planning and optimization of small-scale plants. The addition of 


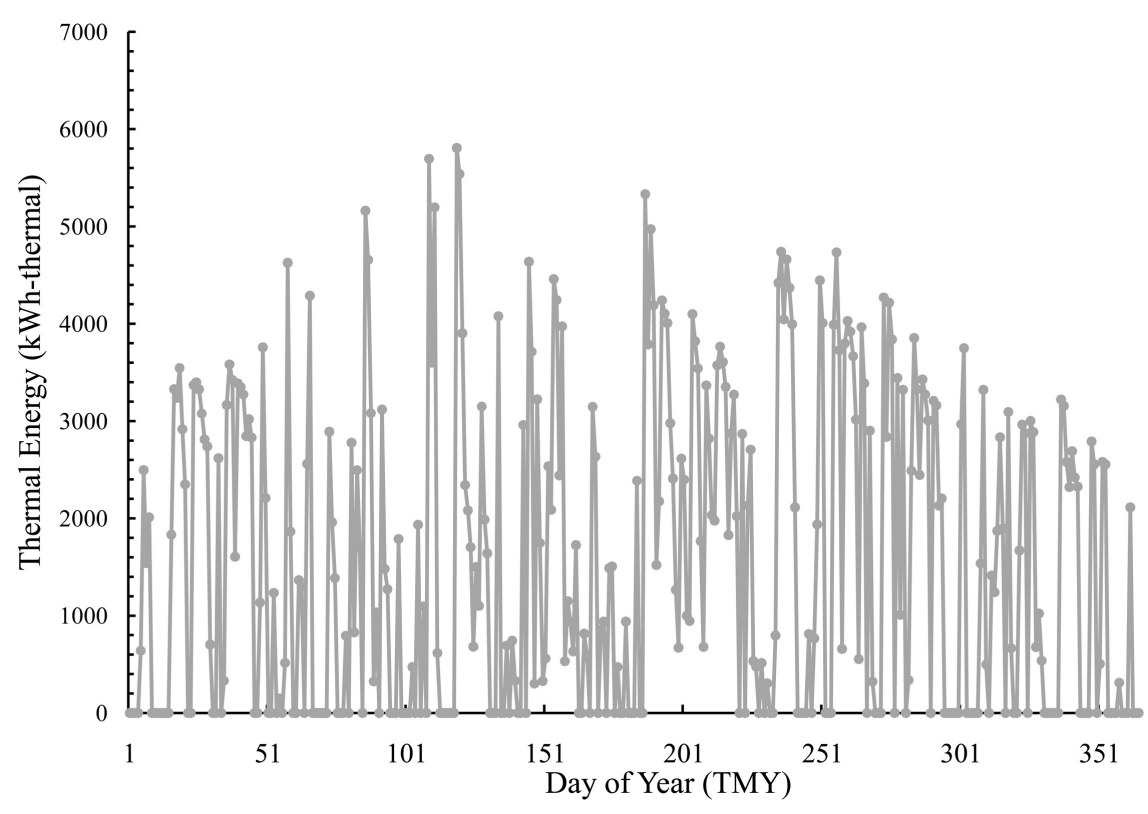

Figure 24. Predicted daily thermal energy from collector field.

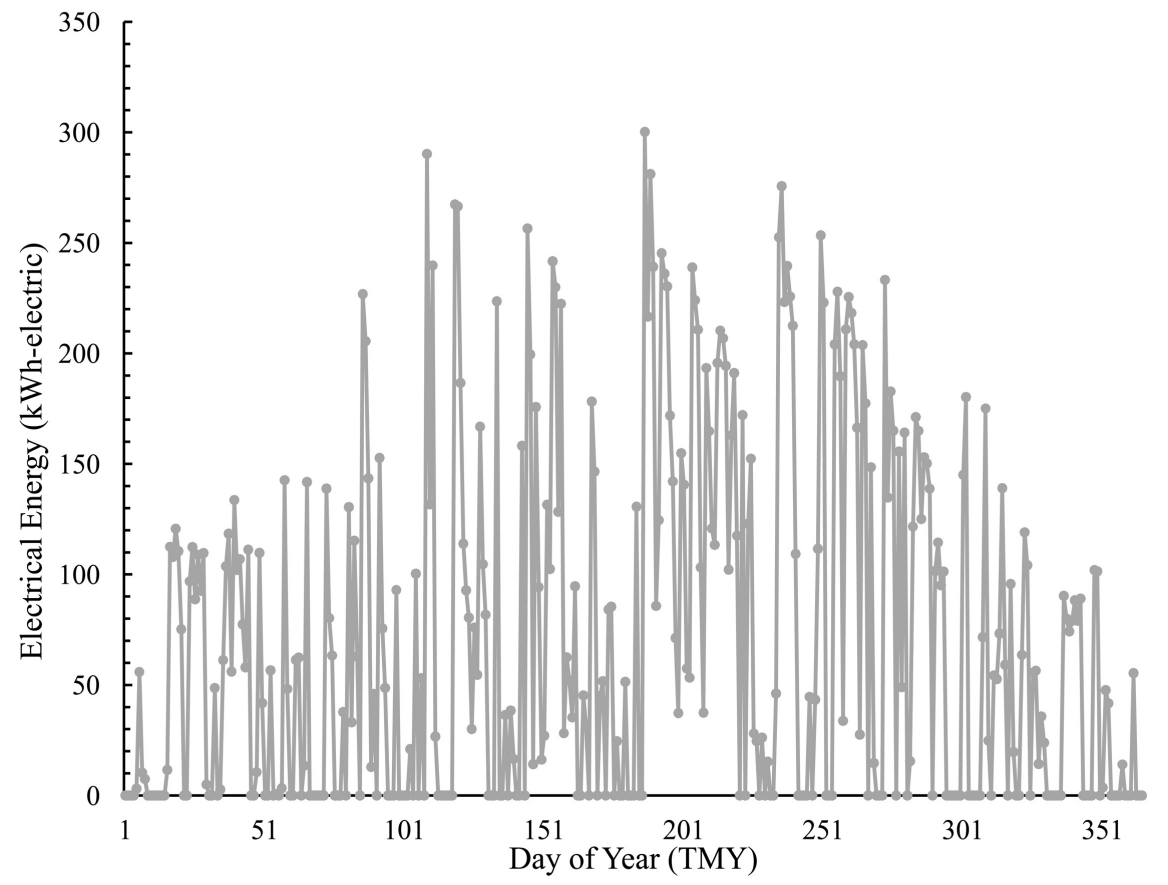

Figure 25. Predicted daily electric energy from plant.

validation data to the numerical model produces a quantifiable uncertainty, so that the usefulness of the model is increased. A simple Rankine cycle model generated results with relatively low uncertainties. The greatest error occurred in the solar field, where additional modeling focus should be applied, especially when storage strategies are to be considered in future work. A thermal buffer will level and smooth the input to the power block, reducing transient effects that the model generated but were not measured physically. There was greater 


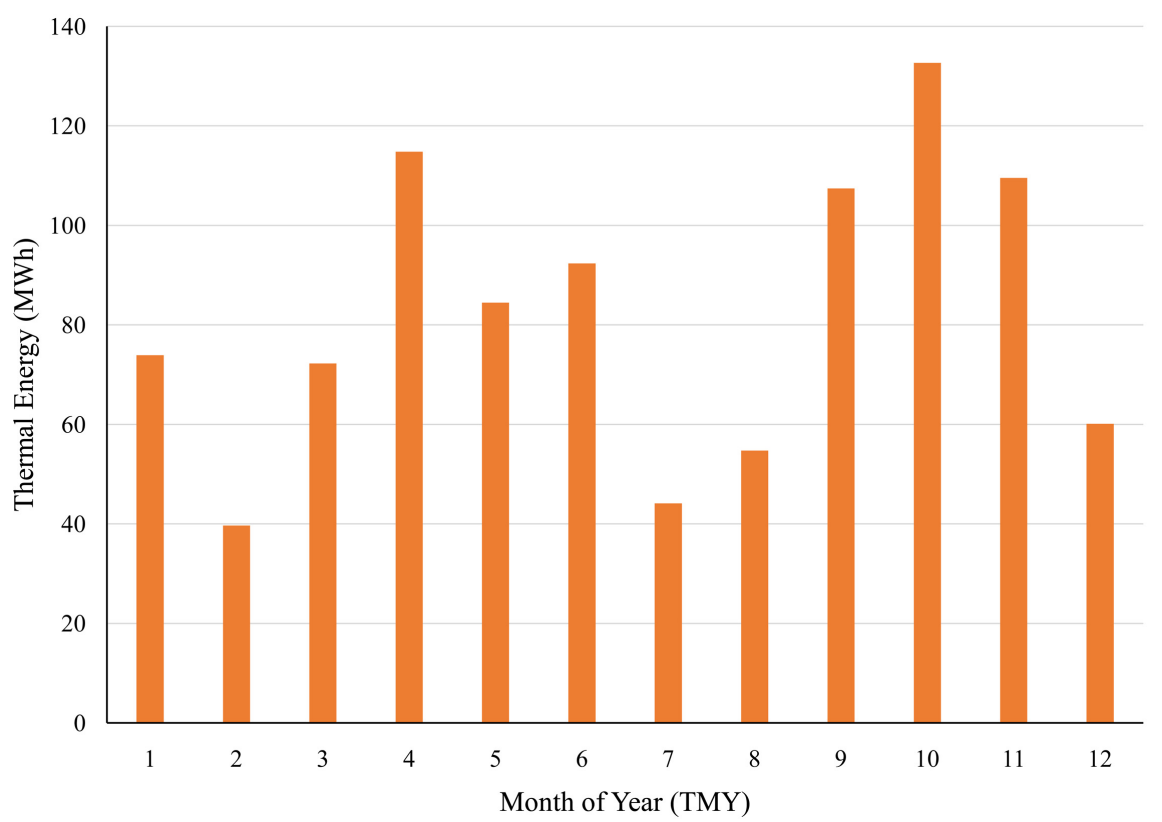

Figure 26. Predicted monthly thermal energy from collector field.

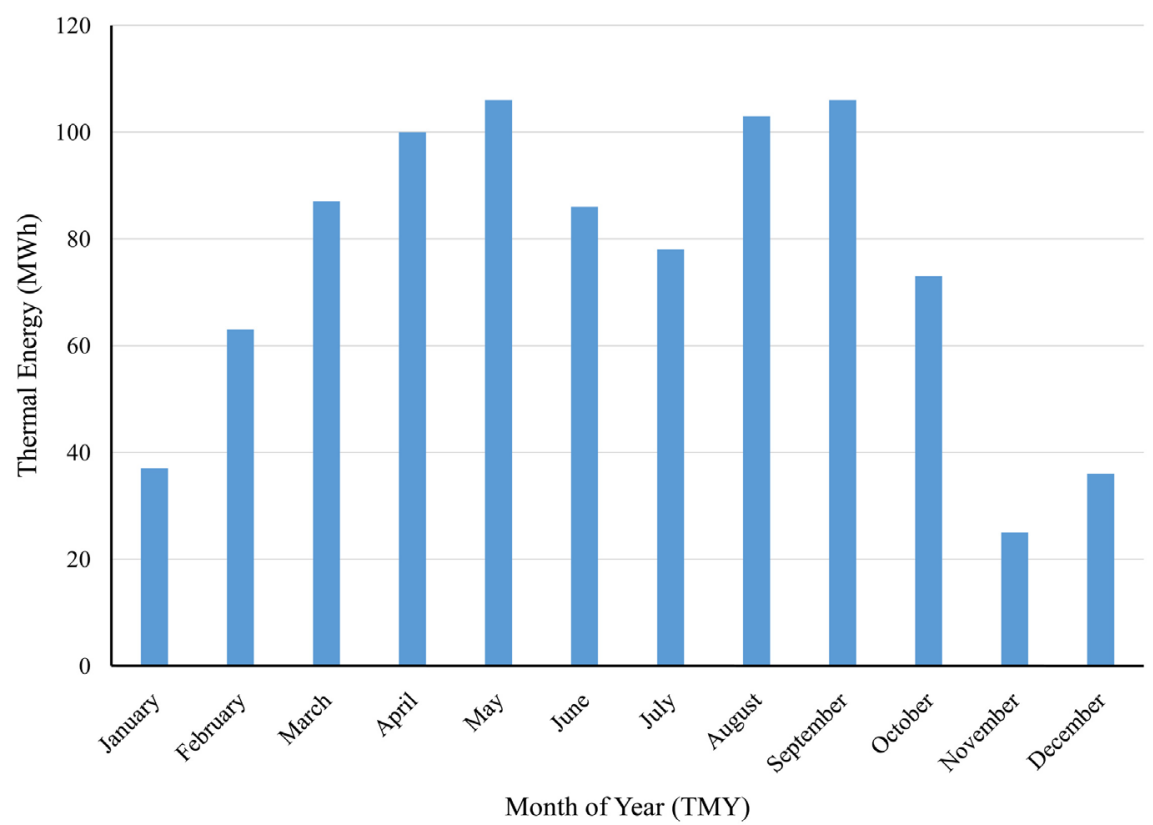

Figure 27. GSF predicted thermal energy output from collector field.

deviation in the seasonal winter data, accounted for by larger radiative losses than accounted for in the model in uninsulated areas of the balance of plant. IAMs for the site are not included in the model which will be more pronounced in the winter season. Negative deviation from the model is expected in both seasons due to ideal assumptions of specularity and tracking error. Transient effects and thermal inertia created significant discrepancies in the solar field data. These occurrences cannot be accurately modeled in the system model due to the fact that the model is in effectively steady state. 


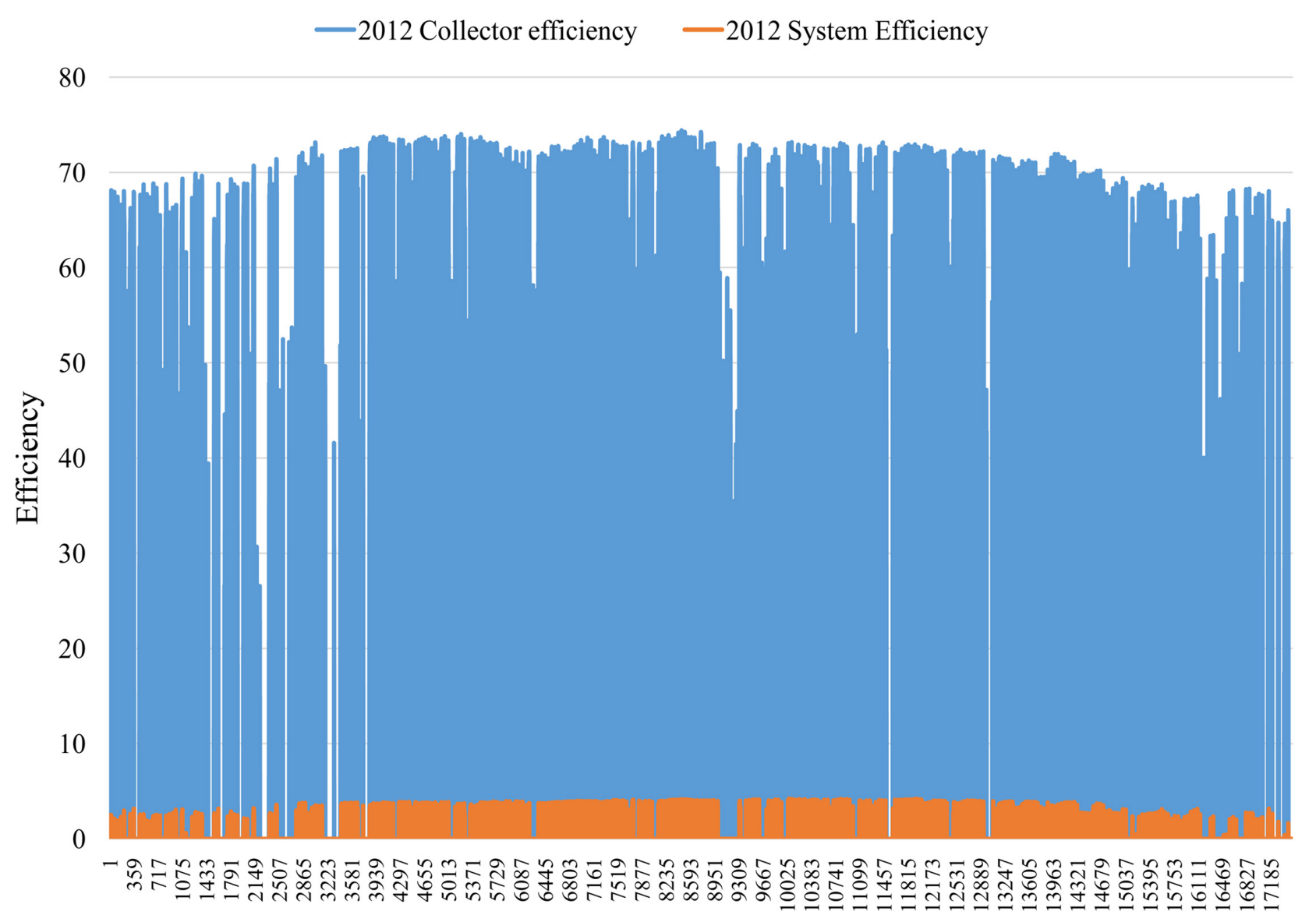

Time $(0.5 \mathrm{hrs} /$ point $)$

Figure 28. Daily predicted collector and system efficiency.

Overall, the model predicted the performance of the within acceptable limits for preliminary planning purposes and system optimization, yielding system errors between 10 and 15 percent. The errors can be primarily attributed to thermal inertia and transient changes in the measured data.

Future work includes the comparison of monthly and yearly experimental data to the model. Additional options will be included, such as variable flowrates in the collector field and updating to a transient model. Focus will be on the improvement of the solar loop heat transfer model without adding to complexity in required input parameters. Economic calculations will also be included for future plant planning. Case studies will be developed on the use of solar irradiance forecast for optimized operation strategies of solar thermal power plants.

\section{Acknowledgements}

This study was supported by Cleco Power, LLC. The original CSP installation was supported by Cleco Power, LLC, and the DOE through the Louisiana Department of Natural Resources and the Empower Louisiana-Renewable Energy Program, grant number RE-06. 


\section{Conflicts of Interest}

The authors declare no conflicts of interest regarding the publication of this paper.

\section{References}

[1] Mejia, F.A. and Kleissl, J. (2013) Soiling Losses for Solar Photovoltaic Systems in California. Solar Energy, 95, 357-363. https://doi.org/10.1016/j.solener.2013.06.028

[2] Lakhani, S., Raul, A. and Saha, S.K. (2017) Dynamic Modelling of ORC-Based Solar Thermal Power Plant Integrated with Multitube Shell and Tube Latent Heat Thermal Storage System. Applied Thermal Engineering, 123, 458-470.

https://doi.org/10.1016/j.applthermaleng.2017.05.115

[3] Al-Maliki, W.A.K., Alobaid, F., Kez, V. and Epple, B. (2016) Modelling and Dynamic Simulation of a Parabolic Trough Power Plant. Journal of Process Control, 39, 123-138.

[4] Yaïci, W. and Entchev, E. (2016) Adaptive Neuro-Fuzzy Inference System Modelling for Performance Prediction of Solar Thermal Energy System. Renew. Energy, 86, 302-315. https://doi.org/10.1016/j.renene.2015.08.028

[5] Barcia, L., Peón Menéndez, R., Martínez Esteban, J., José Prieto, M., Martín Ramos, J., de Cos Juez, F. and Nevado Reviriego, A. (2015) Dynamic Modeling of the Solar Field in Parabolic Trough Solar Power Plants. Energies, 8, 13361-13377. https://doi.org/10.3390/en81212373

[6] Bocci, E., Villarini, M., Vecchione, L., Sbordone, D., Di Carlo, A. and Dell'Era, A. (2015) Energy and Economic Analysis of a Residential Solar Organic Rankine Plant. Energy Procedia, 81, 558-568. https://doi.org/10.1016/j.egypro.2015.12.135

[7] Habib, L., Hassan, M.I. and Shatilla, Y. (2015) A Realistic Numerical Model of Lengthy Solar Thermal Receivers Used in Parabolic Trough CSP Plants. Energy Procedia, 75, 473-478. https://doi.org/10.1016/j.egypro.2015.07.427

[8] El Hefni, B. and Soler, R. (2015) Dynamic Multi-configuration Model of a $145 \mathrm{MWe}$ Concentrated Solar Power Plant with the ThermoSysPro Library (Tower Receiver, Molten Salt Storage and Steam Generator). Energy Procedia, 69, 1249-1258. https://doi.org/10.1016/j.egypro.2015.03.160

[9] Hernández Arriaga, I., Zaversky, F. and Astrain, D. (2015) Object-Oriented Modeling of Molten-Salt-Based Thermocline Thermal Energy Storage for the Transient Performance Simulation of Solar Thermal Power Plants. Energy Procedia, 69, 879-890. https://doi.org/10.1016/j.egypro.2015.03.116

[10] Kronhardt, V., Alexopoulos, S., Reißel, M., Latzke, M., Rendón, C., Sattler, J. and Herrmann, U. (2015) Simulation of Operational Management for the Solar Thermal Test and Demonstration Power Plant Jülich Using Optimized Control Strategies of the Storage System. Energy Procedia, 69, 907-912.

https://doi.org/10.1016/j.egypro.2015.03.172

[11] Luo, N., Yu, G., Hou, H.J. and Yang, Y.P. (2015) Dynamic Modeling and Simulation of Parabolic Trough Solar System. Energy Procedia, 69, 1344-1348. https://doi.org/10.1016/j.egypro.2015.03.137

[12] De Oliveira Siqueira, A.M., Gomes, P.E.N., Torrezani, L., Lucas, E.O. and Da Cruz Pereira, G.M. (2014) Heat Transfer Analysis and Modeling of a Parabolic Trough Solar Collector: An Analysis. Energy Procedia, 57, 401-410. https://doi.org/10.1016/j.egypro.2014.10.193 
[13] Filho, V.C.P., De Sá, A.B., Passos, J.C. and Colle, S. (2014) Experimental and Numerical Analysis of Thermal Losses of a Parabolic Trough Solar Collector. Energy Procedia, 57, 381-390. https://doi.org/10.1016/j.egypro.2014.10.191

[14] Manenti, F. and Ravaghi-Ardebili, Z. (2013) Dynamic Simulation of Concentrating Solar Power Plant and Two-Tanks Direct Thermal Energy Storage. Energy, 55, 89-97. https://doi.org/10.1016/j.energy.2013.02.001

[15] Wagner, P.H. and Wittmann, M. (2013) Influence of Different Operation Strategies on Transient Solar Thermal Power Plant Simulation Models with Molten Salt as Heat Transfer Fluid. Energy Procedia, 49, 1652-1663. https://doi.org/10.1016/j.egypro.2014.03.174

[16] Bonilla, J., Yebra, L.J., Dormido, S. and Zarza, E. (2012) Parabolic-Trough Solar Thermal Power Plant Simulation Scheme, Multi-Objective Genetic Algorithm Calibration and Validation. Solar Energy, 86, 531-540. https://doi.org/10.1016/j.solener.2011.10.025

[17] Huang, W., Hu, P. and Chen, Z. (2012) Performance Simulation of a Parabolic Trough Solar Collector. Solar Energy, 86, 746-755. https://doi.org/10.1016/j.solener.2011.11.018

[18] Powell, K.M. and Edgar, T.F. (2012) Modeling and Control of a Solar Thermal Power Plant with Thermal Energy Storage. Chemical Engineering Science, 71, 138-145. https://doi.org/10.1016/j.ces.2011.12.009

[19] Warner, N.A. (2011) Modelind of a CSP Plant.

[20] Salazar, G.A., Fraidenraich, N., de Oliveira, C.A.A., de Castro Vilela, O., Hongn, M. and Gordon, J.M. (2017) Analytic Modeling of Parabolic Trough Solar Thermal Power Plants. Energy, 138, 1148-1156. https://doi.org/10.1016/j.energy.2017.07.110

[21] Mcmahan, A.C. and Science, M.O.F. (2006) Design \& Optimization of Organic Rankine Cycle Solar-Thermal Power Plants by.

[22] Bruno, J.C., López-Villada, J., Letelier, E., Romera, S. and Coronas, A. (2008) Modelling and Optimisation of Solar Organic Rankine Cycle Engines for Reverse Osmosis Desalination. Applied Thermal Engineering, 28, 2212-2226. https://doi.org/10.1016/j.applthermaleng.2007.12.022

[23] Gilman, P., Blair, N., Mehos, M., Christensen, C., Janzou, S. and Cameron, C. (2008) Solar Advisor Model: User Guide for Version 2.0. 133. https://doi.org/10.2172/937349

[24] Prabhu, E. (2006) Solar Trough Organic Rankine Electricity System (STORES) Stage 1: Power Plant Optimization and Economics.

[25] Olivenza-León, D., Medina, A. and Calvo Hernández, A. (2015) Thermodynamic Modeling of a Hybrid Solar Gas-Turbine Power Plant. Energy Conversion and Management, 93, 435-447. https://doi.org/10.1016/j.enconman.2015.01.027

[26] Quoilin, S., Orosz, M., Hemond, H. and Lemort, V. (2011) Performance and Design Optimization of a Low-Cost Solar Organic Rankine Cycle for Remote Power Generation. Solar Energy, 85, 955-966. https://doi.org/10.1016/j.solener.2011.02.010

[27] Quoilin, S., Orosz, M. and Lemort, V. (2008) Modeling and Experimental Investigation of an Organic Rankine Cycle Using Scroll Expander for Small Scale Solar Applications. International Conference on Solar Heating, Cooling and Buildings, Lisbon, 7-10 October 2008, 1-8.

[28] Mitterhofer, M. and Orosz, M. (2015) Dynamic Simulation and Optimization of a Micro-CSP Power Plant.

[29] Wittmann, M., Breitkreuz, H., Schroedter-Homscheidt, M. and Eck, M. (2008) Case 
Studies on the Use of Solar Irradiance Forecast for Optimized Operation Strategies of Solar Thermal Power Plants. IEEE Journal of Selected Topics in Applied Earth Observations and Remote Sensing, 1, 18-27.

[30] Price, H. (2003) A Parabolic Trough Solar Power Plant Simulation Model. International Solar Energy Conference, Hawaii, 16-18 March 2003, 665-673.

[31] MathWorks. Simulink-Simulation and Model-Based Design.

[32] Quoilin, S., Van Den Broek, M., Declaye, S., Dewallef, P. and Lemort, V. (2013) Techno-Economic Survey of Organic Rankine Cycle (ORC) Systems. Renewable \& Sustainable Energy Reviews, 22, 168-186. https://doi.org/10.1016/j.rser.2013.01.028

[33] Pan, Z. (2012) Fast Modeling and Performance Analysis of a Concentrated Solar Thermal Power Plant. University of Louisiana, Lafayette.

[34] ElectraTherm. http://electratherm.com/

[35] Forristall, R. (2003) Heat Transfer Analysis and Modeling of a Parabolic Trough Solar Receiver Implemented in Engineering Equation Solver.

[36] Marion, W.F. and Dobos, A.P. (2013) Rotation Angle for the Optimum Tracking of One-Axis Trackers Rotation Angle for the Optimum Tracking of One-Axis Trackers.

[37] Duffie, J.A. and Beckman, W.A. (2013) Solar Engineering of Thermal Processes. 4th Edition, Wiley, Hoboken. https://doi.org/10.1002/9781118671603

[38] Çengel, Y.A. and Boles, M.A. (2014) Thermodynamics: An Engineering Approach. 8th Edition, McGraw-Hill Education, New York.

[39] Stull, R. (2011) Wet-Bulb Temperature from Relative Humidity and Air Temperature. Journal of Applied Meteorology and Climatology, 50, 2267-2269. https://doi.org/10.1175/JAMC-D-11-0143.1

[40] Kipp \& Zonen (2013) CHP-1 Pyrheliometer Instruction Manual.

[41] Kipp \& Zonen (2013) CMP Series Pyranometer Instruction Manual. 